\title{
Modulation of the DNA-Damage Response by Inhibitors of the Phosphatidylinositol 3-Kinase Related Kinase (PIKK) Family
}

\author{
Suzannah Harnor, James Pickles, and Celine Cano
}

\begin{abstract}
The ability of cancer cells to repair DNA damage is an important determinant of their susceptibility to DNA-damaging anticancer therapies, and inhibition of DNA-repair processes can thus lead to the potential therapeutic endpoints of radio- and chemo-sensitisation. As such, a number of agents that target DNA-repair enzymes are currently the subject of clinical trials. The phosphatidylinositol 3-kinase related kinase (PIKK) family of enzymes, which includes DNA-dependent protein kinase (DNA-PK), ataxia-telangiectasia mutated (ATM), ataxia-telangiectasia mutated related (ATR), mammalian target of rapamycin (mTOR) and hSMG1, are thought to act as nucleic acid surveillance proteins. DNA-PK and ATM, the normal function of which is lost in ataxiatelangiectasia, both play an important role in the detection and repair of DNA double-strand breaks (DSBs). DNA-PK is an essential component of the non-homologous end-joining (NHEJ) pathway of DNA DSB repair, whilst ATM signals to cell cycle and DNA-repair components by phosphorylating multiple downstream targets, including p53, checkpoint kinase 2 (CHK2), NBS1 and BRCA1. Crucially, loss of DNA-PK or ATM activity results in an increased sensitivity to ionising radiation and certain chemotherapeutic agents that elicit DNA DSBs. These kinases therefore represent attractive targets for the development of radio- and chemo-sensitising agents.
\end{abstract}

Keywords Chemopotentiation, DNA damage, Inhibitor, Kinase, Radiopotentiation

S. Harnor, J. Pickles, and C. Cano ( $\triangle)$

Northern Institute for Cancer Research, School of Chemistry, Newcastle University, Newcastle upon Tyne NE1 7RU, UK

e-mail: celine.cano@newcastle.ac.uk 


\section{Contents}

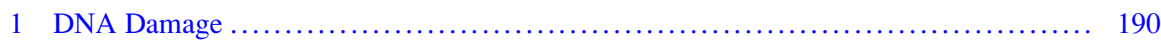

$1.1 \quad$ DNA Inter- and Intra-strand Crosslinks ................................ 190

1.2 DNA Backbone Damage ............................................ 191

1.3 DNA Base Damage ................................................. 191

2 The DNA-Damage Response ............................................ 193

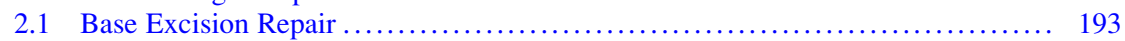

2.2 Nucleotide Excision Repair .............................................. 193

2.3 Mismatch Repair ................................................... 194

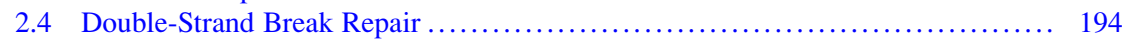

3 The Phosphatidylinositol 3-Kinase Related Kinase Family ...................... 196

$3.1 \quad$ DNA-Dependent Protein Kinase ....................................... 197

3.2 Ataxia-Telangiectasia Mutated Kinase ............................... 208

3.3 Ataxia-Telangiectasia and Rad3-Related Kinase ......................... 212

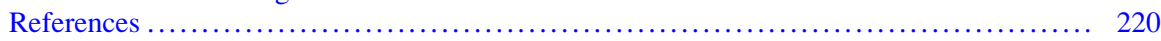

\section{DNA Damage}

DNA within cells is constantly exposed to damage, which requires repair in order for the integrity of DNA to be maintained. Damage to DNA can lead to harmful mutations, which affect normal cellular processes and can cause cancer if left unrepaired. DNA is intrinsically susceptible to modification by reactive species and estimates suggest that there are in the region of $10^{16}-10^{18}$ repair events which take place in a human on a daily basis [1].

Fortunately, cells have evolved efficient processes for the repair of DNA damage, collectively known as the DNA-damage response (DDR) (Fig. 1) [2]. Examples of endogenous damaging agents are ROS from cellular metabolism and endogenous methylating agents, whereas damage can be induced from external sources such as ultraviolet (UV) light and xenobiotics and in response to established cancer treatment such as DNA-damaging chemotherapy and ionising radiation [3, 4].

\subsection{DNA Inter- and Intra-strand Crosslinks}

Well-characterised forms of DNA damage include inter- and intra-strand crosslinks. A covalent bond is formed between two bases on opposite strands of DNA in the case of an inter-strand crosslink and within the same strand with intrastrand crosslinks [5]. Inter-strand crosslinks are extremely toxic to the cell as they prevent the separation of the different strands, an important part of both DNA replication and transcription [5]. Intra-strand crosslinks are less toxic given that they can be bypassed by certain enzymes. The nitrogen mustards are known to elicit this type of damage [6]. 


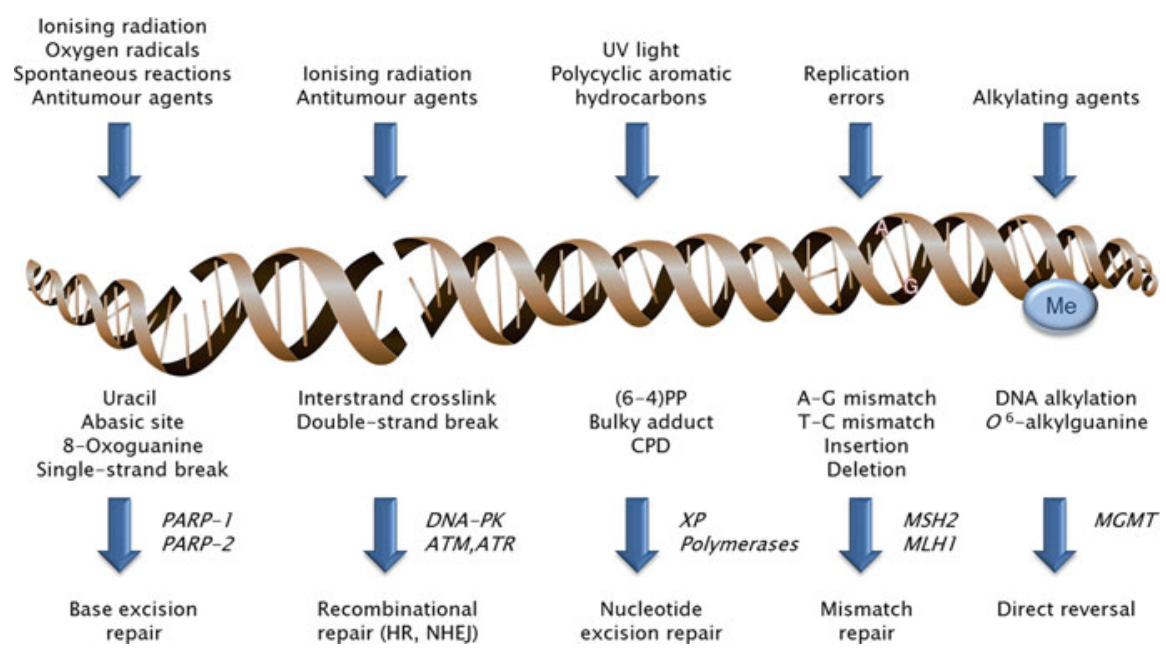

Fig. 1 DNA damage and response. Adapted from Hoeijmakers [2]

\subsection{DNA Backbone Damage}

Deoxyribose moieties within the DNA backbone are particularly susceptible to attack by ROS generated intracellularly [6]. Hydroxyl radicals, for example, can abstract a hydrogen atom from the sugar to give a radical species which, after degradation, can result in a break to the DNA backbone. The structural units $\mathbf{1}$, $\mathbf{2}$ and $\mathbf{3}$ are all formed in this manner [7]. These single-strand breaks (SSBs) can be repaired by base excision repair (BER) but when numerous SSBs occur in close proximity to one another, a DNA double-strand break (DSB) can be formed $[6,8]$. Ionising radiation is capable of inducing DNA DSBs and these lesions are the most cytotoxic to the cell.<smiles>CCOP(=O)([O-])O</smiles>

1<smiles>CCOP(=O)([O-])OC(=O)[O-]</smiles>

2<smiles>COP(=O)([O-])OCC=O</smiles>

3

\subsection{DNA Base Damage}

Abasic sites can be produced when the glycosidic bond in DNA is hydrolysed (Scheme 1), which is a very common occurrence. It has been estimated that this process can occur 10,000 times per cell per day [9]. Loss of a base is harmful to the 


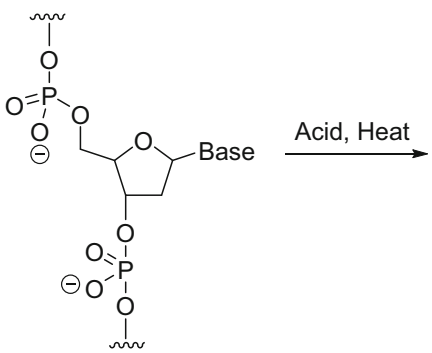

4

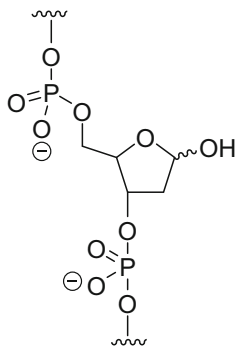

6

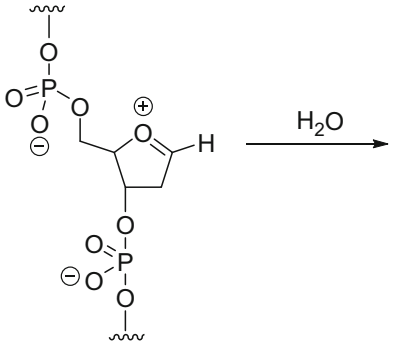

5

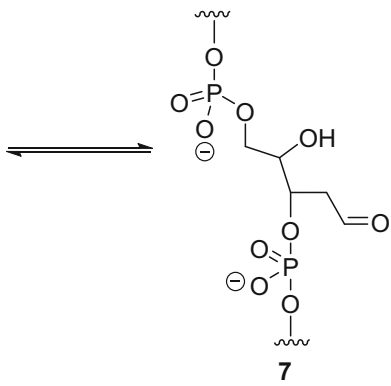

Scheme 1 Mechanism by which abasic sites are formed on DNA [9]<smiles></smiles>

Scheme 2 Deamination of cytosine (8) to yield uracil (9)

cell for two reasons. Firstly, this can lead to mutations when the DNA is replicated and, secondly, SSBs can also occur if they are left untreated $[6,10]$.

Deamination is another process which may impair the DNA sequence and this occurs on amino groups of bases, most commonly on cytosine (8). Compound $\mathbf{8}$ can undergo nucleophilic attack by water and, following liberation of ammonia, uracil (9) is produced (Scheme 2), resulting in a change in the genetic code.

External agents such as UV radiation can cause damage to DNA bases as Fig. 9 shows. UV light leads to the formation of photoadducts such as the cyclobutane dimer (10) [6]. Xenobiotics such as polycyclic hydrocarbons can, upon metabolic activation, react with DNA, leading to the formation of bulky adducts such as $\mathbf{1 1}$. Due to the steric bulk added by such modifications, they interfere with the secondary structure of DNA and this can affect cellular processes such as transcription [6]. 


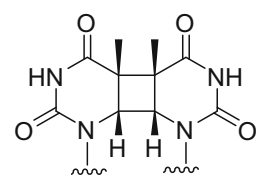

10

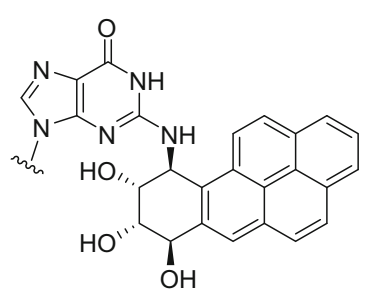

11

\section{The DNA-Damage Response}

The wide diversity of DNA-lesion types necessitates multiple, largely distinct DNA-repair mechanisms.

\subsection{Base Excision Repair}

BER, discovered by Lindhal, is a DDR process employed when, for example, oxygen radicals and alkylating agents act on genetic material (Fig. 1) [11]. The BER pathway relies on proteins recognising the damage [11]. The downstream effect of this impairment is often mutations, which is clearly disadvantageous. Interestingly, this error free repair mechanism can occur via one of the two mechanisms, short-patch repair (in which a single nucleotide is replaced) or longpatch repair (where at least two nucleotides are replaced) [11, 12]. However, it is poorly understood as to what determines which of these options is undertaken. Short-patch repair does, nevertheless, constitute the main pathway [2]. Essentially, a damaged base is replaced in order to prevent potentially dangerous mutations [11].

\subsection{Nucleotide Excision Repair}

Nucleotide excision repair (NER) acts on the products of damage induced in DNA by UV light or with any covalent adducts (Fig. 1) and occurs during G1 phase of the cell cycle [13, 14]. Altogether, a broad range of damage is repaired via this mechanism and it can be subdivided into three subcategories: global genome repair (GGR), transcription-coupled repair (TCR) and transcription domain-associated repair (DAR) [14]. TCR, as the name suggests, is coupled to transcription, DAR 
works on both strands of active genes and GGR is any other NER that occurs [14]. Unlike BER, NER does not rely on having specific enzymes each recognising a different lesion; instead, inaccuracies in the structure of genetic material are enough to trigger a response [14]. Following identification of the damage, the site of impairment is removed, leaving a break which DNA polymerases act upon to liberate the repaired DNA [14].

\subsection{Mismatch Repair}

DNA has to be duplicated many times in order to pass vital genetic information on from one generation to the next, a process which is not without error. Fortunately, there is a repair mechanism that can recognise faults in the daughter strand postreplication [15]. Mismatch repair (MMR) maintains genetic integrity by correcting insertions, deletions and discrepancies in base pairings [2, 13]. Figure 2 shows the key phases involved in MMR. In Stage I (upper strand), hMSH2/6 recognises non-complimentary bases whereas hMSH2/3 recognises insertion/deletion errors (Stage II, lower strand). Following recognition, other essential proteins, for example, mutator S (MutS), are recruited, exonucleases excise the errors and, finally, resynthesis can occur (Stage III) [2].

\subsection{Double-Strand Break Repair}

Although less prevalent than other DNA lesions, the DSB is considered to be the most cytotoxic and difficult to repair and there is evidence to suggest that a single DSB may prove lethal to a cell [16]. Two principal mechanisms are responsible for the repair of DSBs, namely the error free homologous recombination (HR) process, and non-homologous end joining (NHEJ), which is an error-prone ligation mechanism (Fig. 3). Whereas HR repair is, by necessity, restricted to S and G2, NHEJ may operate at any phase of the mitotic cell cycle, although this repair process occurs predominantly in G1 and G0 [1, 18]. Importantly, initiation of the DDR as a consequence of DSB detection has far reaching implications within a cell, resulting in the activation of a complex signalling network, which modulates cell cycle progression, gene expression and protein synthesis [1, 19]. Members of an atypical class of protein kinases termed the phosphatidylinositol (PI) 3-kinase related kinase (PIKK) family are major players in the detection, signalling and repair of DNA DSBs.

The process of HR is initiated, following DSB detection, by the Rad50/Mre11/ NBS1 (MRN) complex (Fig. 3a). This complex performs a nucleolytic resection to expose single-stranded $3^{\prime}$ overhangs of double-stranded DNA, which facilitates binding of a RAD51 nucleoprotein filament [20]. This nucleoprotein filament has the capability to exchange the single strand of DNA with the identical sequence in a 
Fig. 2 The process by which DNA is repaired by mismatch repair (MMR) [2]. In Stage I, heterodimers of $\mathrm{hMSH} 2 / 6$ focus on mismatches and single-base loops, whereas in Stage II, hMSH2/3 dimers recognise insertion/deletion loops. In Stages II and III, a number of proteins, including exonuclease 1 , are associated in the excision of the new strand past the mismatch and resynthesis steps

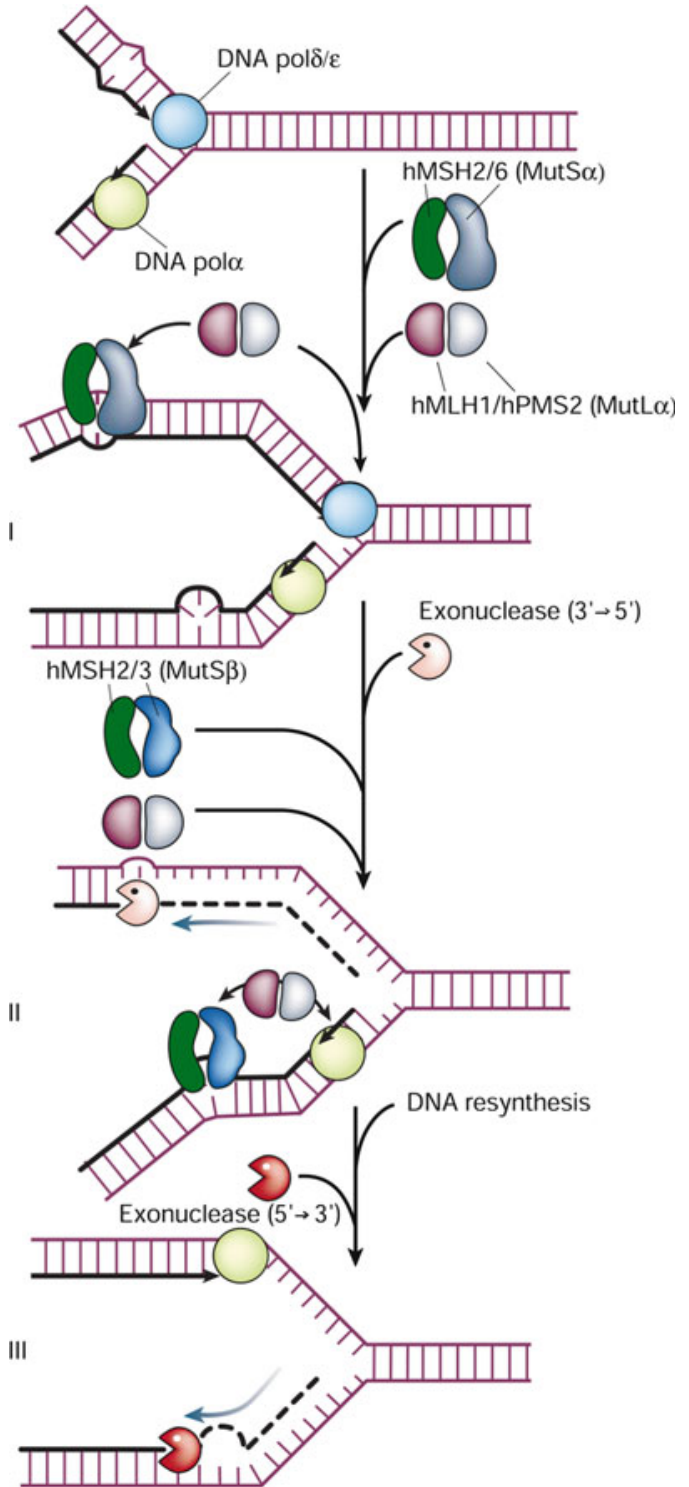

double-stranded DNA counterpart. The intact double-stranded copy is then used as a template to repair the DSB by the action of DNA ligases [21]. The DNA strand invasion results in the formation of Holliday junctions. These are mobile junctions between four strands of DNA that are repaired by resolvase enzymes thus completing the overall repair process [22].

NHEJ can operate at any stage of the cell cycle as it does not require a DNA template for the restoration process but it predominantly acts at G1 and G0 (Fig. 3b). NHEJ functions by directly ligating the end of DNA DSBs 
A

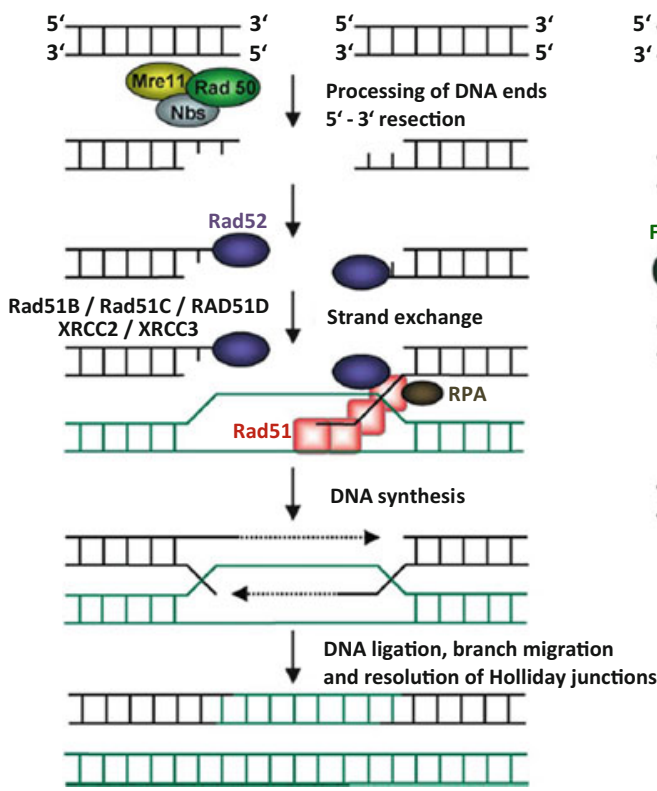

B
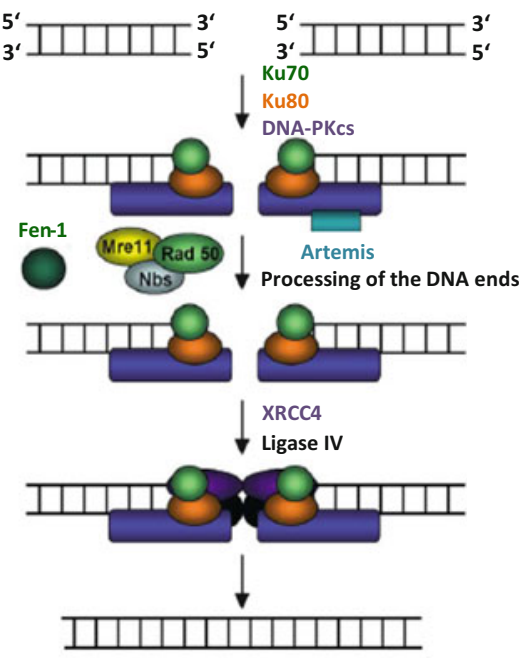

Fig. 3 Recombinational repair processes [17]. (a) Mechanism of homologous recombination (HR). Nucleolytic resection of DSB in direction $5^{\prime} \rightarrow 3^{\prime}$ by the MRE11-Rad50-NBS1 complex forms a $3^{\prime}$ single-stranded DNA fragment. Rad 52 binds, and interacts with Rad51 to elicit a DNA strand exchange with undamaged, homologous DNA molecule. The resulting structure is resolved after DNA synthesis, ligation and branch migration. (b) Mechanism of non-homologous end joining (NHEJ). Ku70-Ku80 complex binds to damaged DNA, and then the Ku heterodimer binds to catalytic subunit of the DNA-dependent protein kinase (DNA-PKcs) to form the DNA-PK holoenzyme. The X-Ray repair cross complementing 4 (XRCC4)-ligase IV is activated by DNA-PK, which links the broken DNA ends

$[23,24]$. NHEJ is a rapid process, compared to HR, but can sometimes result in a loss/gain of nucleotides [2].

\section{The Phosphatidylinositol 3-Kinase Related Kinase Family}

The phosphatidylinositol 3-kinase related kinase (PIKK) family is a group of six atypical serine/threonine protein kinases (Fig. 4). They are so named due to their similarities with the phosphoinositide 3-kinase (PI3K) family which are a series of lipid kinases possessing a variety of biological activities.

Comprising the PIKK family are DNA-PK, ataxia-telangiectasia mutated (ATM), ataxia-telangiectasia mutated related kinase (ATR), mammalian target of rapamycin (mTOR), transformation/transcription domain-associated protein 


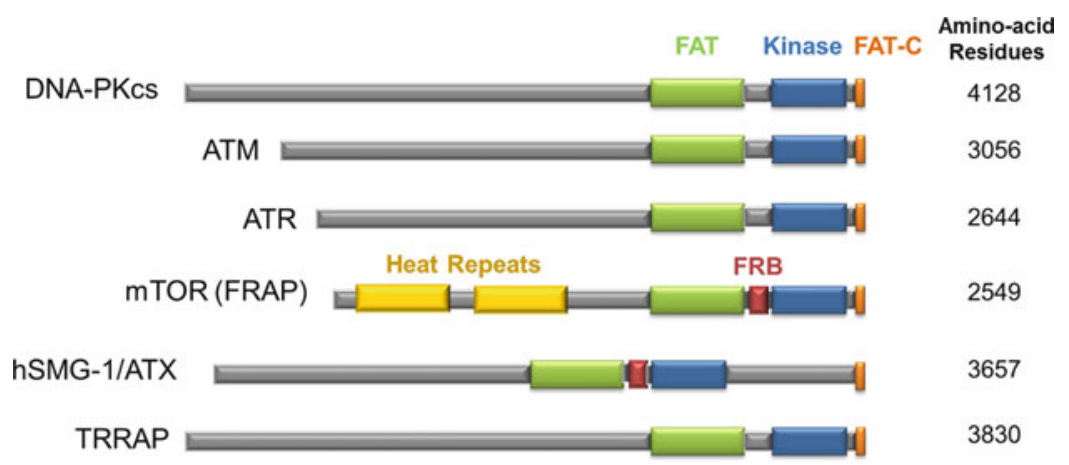

Fig. 4 The phosphatidylinositol 3-kinase related kinase (PIKK) family of atypical protein kinases. Adapted from Ref. [25]

(TRRAP) and suppressor of morphogenesis in genitalia 1 (SMG-1). ATM, ATR and DNA-PK are all involved in DNA repair and are discussed further later. mTOR is involved in organismal growth and homeostasis whilst SMG-1 is involved in nonsense-mediated RNA decay [26, 27].

The PIKK proteins consist of a PI3K domain and, also, FRAP-ATM-TRAPP (FAT) and FAT carboxy-terminal (FATC) regions surrounding the catalytic region, with FAT being located on the $N$-terminal side. Although some of the functions of these domains remain unclear, it has been reported that the FAT domain of ATM contains a serine residue which is key for the activation of the kinase [25].

\subsection{DNA-Dependent Protein Kinase}

\subsubsection{Structural Features of DNA-Dependent Protein Kinase}

The DNA-PK catalytic subunit is the largest of the PIKK family members, consisting of a polypeptide of 4,128 amino acids. Owing to the large size of the peptide, crystal structure determination has proven challenging. However, in January 2010 Sibonda et al. published the first known crystal structure of DNA-PKcs in complex with C-terminal fragments of Ku80 (the $80 \mathrm{kDa}$ protein subunit of the Ku complex, also known as ATP-dependent DNA helicase II), albeit at a resolution of $6.6 \AA$ [4]. Whilst this resolution cannot provide useful information on the structure of the ATP-binding domain, it gives a general overview of the structural features of the protein (Fig. 5).

The major role of the Ku70/Ku80 heterodimer within the NHEJ pathway is recognition and binding of DNA ends to facilitate correct alignment for subsequent processing and ligation. The proteins themselves are known to consist of three distinct functional regions. An amino terminal Willebrand A-domain (vWA) is thought to be a protein-protein interacting domain which may play a key role in 


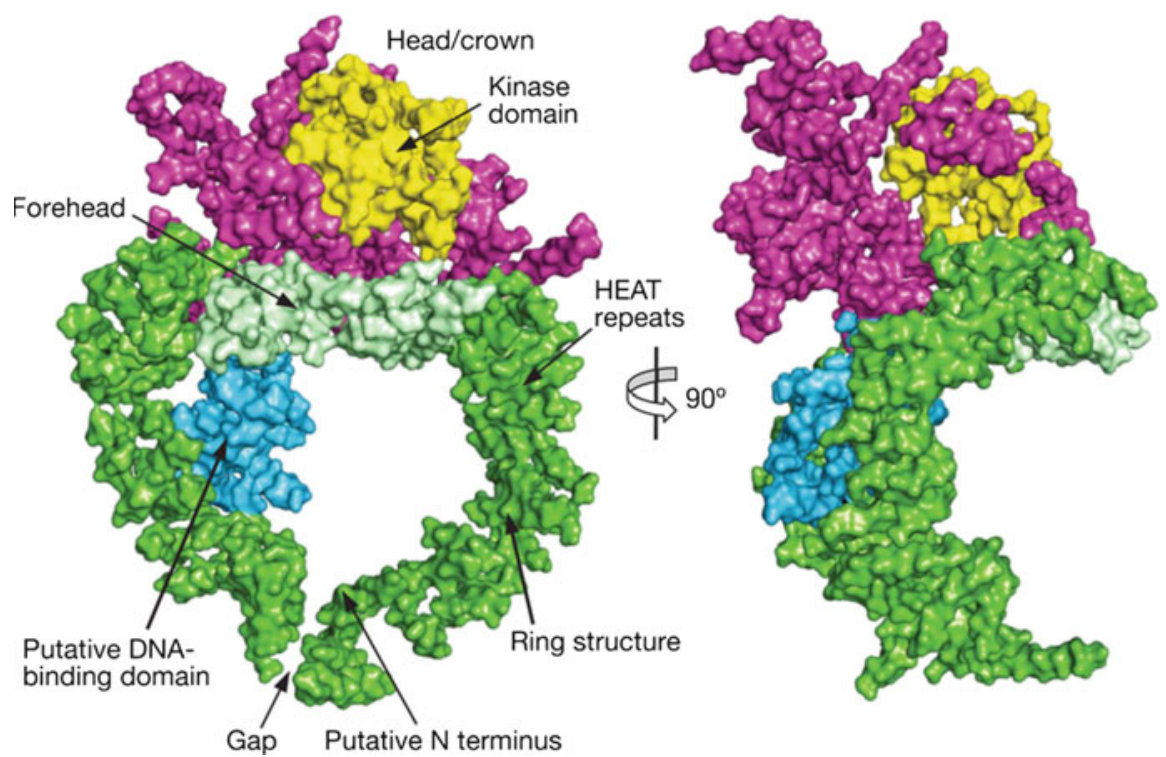

Fig. 5 Crystal structure of DNA-dependent protein kinase (DNA-PKcs). Yellow: kinase domain, green: ring structure, light green: forehead region that is part of the ring structure, blue: putative DNA-binding domain, and magenta: C-terminal region carrying the FRAP-ATM-TRAPP (FAT) and FAT carboxy-terminal (FATC) domains [4]

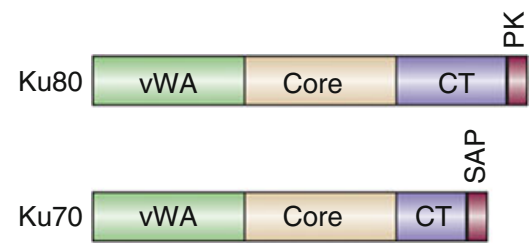

Fig. 6 Depiction of the Ku70 and Ku80 protein domains [28]

heterodimerisation. A central core domain is then linked to a carboxy-terminal region, which in $\mathrm{Ku} 80$ is elongated and contains the regions to which the DNA-PKcs binds (Fig. 6) [28].

\subsubsection{DNA-Dependent Protein Kinase and the Non-homologous End-Joining DNA-Repair Pathway}

As previously mentioned, the major pathway for DSB repair in non-replicating mammalian cells is NHEJ, and DNA-PK plays a key role in this process (Fig. 3). The Ku70/Ku80 heterodimer is responsible for binding to the broken DNA ends [29]. $\mathrm{Ku}$ binds to both of the broken strands and forms a bridging complex to lock the damaged ends in place [30]. The catalytic subunit of the DNA-PKcs is recruited 
to the site of damage to form a 'synaptic complex'. Formation of the holoenzyme greatly enhances the serine/threonine protein kinase activity of DNA-PKcs resulting in autophosphorylation of multiple sites on the protein. A small cluster of seven phosphorylation sites between residues 2,609 and 2,647 are thought to be key for a change in the tertiary structure of the DNA-PK complex, which makes the DNA termini accessible for further processing [31]. DNA docks in the DNA-binding site within DNA-PKcs, which is in the $N$-terminal domain [29]. Should $\mathrm{Ku}$ be absent, then another process can anneal DNA DSBs via alternative NHEJ that involves poly(ADP-ribose) polymerase 1 (PARP1) and XRCC1 [32].

Once the DNA is bound, processing enzymes, such as Artemis and DNA polymerases, locate to the site of damage. Artemis is a nuclease that is phosphorylated by DNA-PKcs following formation of the DNA-PK holoenzyme. It is responsible for the cleavage of non-complementary bases from the DNA termini [33]. Whilst the exact types of lesions requiring Artemis-mediated repair have not been identified, it is thought that $15-20 \%$ of DSBs resulting from the action of ionising radiation remain unrepaired in cells deficient in the Artemis protein [34].

The complexity of the DSBs formed by ionising radiation dictates that, whilst some may require DNA base removal, a number will conversely require base insertion. This role is fulfilled by a number of DNA polymerases, most notably DNA polymerase $\mu$ and $\lambda$, both of which are recruited to the break site through their interaction with $\mathrm{Ku}$ [35]. It has been demonstrated that cells deficient in either DNA polymerase $\mu$ or $\lambda$ are not highly sensitised to ionising radiation, suggesting that these processing factors are only required in a small subset of strand breaks [34].

Current literature reports implicate a number of different processing factors in the NHEJ pathway including PNF, APLF and the WRN complex. The increasing number implicated would seem to suggest that the specific enzymes recruited for end processing may be relatively flexible, depending upon the nature of the break [35].

Upon completion of end processing, the remainder of the pathway is directed towards end ligation. This is performed following the recruitment of a DNA ligase IV/XRCC4 complex to the break site. XRCC4 has no known enzymatic activity but instead acts as a scaffolding protein for the interaction of DNA ligase IV with $\mathrm{Ku}$, and thus the DSB. Binding of XRCC4 to DNA ligase IV promotes its enzymatic activity, which subsequently instigates the ligation and repair of the break site [36].

\subsubsection{DNA-Dependent Protein Kinase Small-Molecule Inhibitors}

Following the discovery that DNA-PK inhibition can potentiate in vitro cytotoxicity of ionising radiation and a number of anticancer drugs, a number of small molecules with DNA-PK inhibitory activity have been developed. To date, the most successful approach to DNA-PK inhibition has been with small molecule targeting the ATP-binding site of the kinase. 


\section{Wortmannin}

The first example within this specific group of compounds is wortmannin (12), a steroidal derivative reported as a potent PI3K inhibitor in 1994 [37].

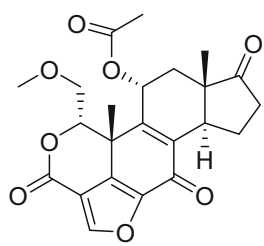

12

Wortmannin is a natural fungal metabolite, derived from Penicillium wortmannii $K$ and first observed to have antifungal and anti-inflammatory properties. This sterol-like compound is a potent and selective inhibitor of PI3K family kinases without activity against other intracellular signalling enzyme targets, inhibiting PI3K activity with an $\mathrm{IC}_{50}$ of $4.2 \mathrm{nM}$ [37]. Kinetic analysis of the PI3K inhibition by wortmannin indicated a non-competitive irreversible inhibition, which was further verified by Williams. et al. with co-crystallographic studies of the resulting covalent complex in the ATP-binding pocket of PI3K $\gamma$ [38, 39]. Further studies demonstrated that wortmannin also inhibits DNA-PK $\left(\mathrm{IC}_{50}=16 \mathrm{nM}\right)$ by a non-competitive mechanism, forming covalent adducts with DNA-PKcs lysine 802 in the region of the molecule harbouring its kinase domain [40]. Although the activity of this sterol-like structure and its mode of interaction make it very attractive, the relative structural complexity of wortmannin, together with its irreversible inhibition and poor selectively, limits its potential as a drug molecule.

Chromen-4-Ones and Surrogates: LY2094002 and Derivatives

The chromen-4-one structure LY294002 (13) was reported by Lilly pharmaceuticals in 1994 as an inhibitor of PI3K [41]. It was identified through a screen of compounds derived from quercetin (14) with the objective of developing PI3Kspecific inhibitors. 
Table 1 Reported inhibitory activity of LY294002 (13) against different PIKK family members

\begin{tabular}{l|l|l|l|l|l}
\hline & DNA-PK & PI3K $\left(\mathrm{p} 110_{\alpha}\right)$ & ATM & ATR & mTOR \\
\hline $\mathrm{IC}_{50}(\mu \mathrm{M})$ & $1.5 \pm 0.2^{\mathrm{a}}$ & $2.3 \pm 0.8^{\mathrm{a}}(1.4)^{\mathrm{b}}$ & $>100^{\mathrm{a}}$ & $>100^{\mathrm{a}}$ & $2.5 \pm 0.2^{\mathrm{a}}$ \\
\hline
\end{tabular}

${ }^{a}$ Values from Ref. [42]

${ }^{\mathrm{b}}$ Literature value from Ref. [41]

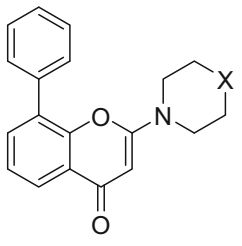

13; $X=0$

15; $X=S$

16; $\mathrm{X}=\mathrm{CH}_{2}$<smiles>O=c1cc(-c2ccc(O)c(O)c2)oc2cc(O)cc(O)c12</smiles>

14

Subsequent evaluation of $\mathbf{1 3}$ as a DNA-PK inhibitor showed that the compound exhibited similar DNA-PK inhibitory activity to that against PI3K, highlighting the non-selective profile of the compound (Table 1) [41, 42].

Research conducted at the Northern Institute for Cancer Research at Newcastle University and KuDOS Pharmaceuticals (now part of AstraZeneca) revealed the importance of the oxygen of the morpholine substituent of 13, and whilst replacement by thiomorpholine (15) dramatically reduced potency, the piperidine derivative 16 proved essentially devoid of DNA-PK inhibitory activity. The key role of the morpholine substituent of $\mathbf{1 3}$ was later confirmed by X-ray crystallography when the structure of $\mathbf{1 3}$ in complex with human PI3K $\gamma$ revealed that the morpholine oxygen makes a hydrogen bond interaction with the backbone amide group of Val-882 within the ATP-binding domain of the kinase (Fig. 7) [39].

Although 13 suffered from rapid metabolic clearance $(1 \mathrm{~h})$, in vivo toxicity and lack of specificity, the compound helped the design of derivatives with improved potency against DNA-PK, selectivity and better physico-chemical properties.

The first generation of analogues were benzopyranone and pyrimidoisoquinolinone derivatives. Incorporation of a fused ring on the chromenone gave a fivefold improvement in potency against DNA-PK $\left(\mathbf{1 7}\right.$; DNA-PK $\left.\mathrm{IC}_{50}=0.23 \mu \mathrm{M}\right)$ (Table 2). Introduction of a methyl group on the morpholine ring gave no improvement in activity against DNA-PK $\left(18\right.$; DNA-PK $\left.\mathrm{IC}_{50}=0.19 \mu \mathrm{M}\right)$. However, additional methyl groups, at the 2- or 6-position of morpholine, or replacement of the morpholine ring (e.g. piperidine, and piperazine) resulted in a loss of activity [42, 43]. Encouragingly, all early derivatives showed better selectivity for DNA-PK over other PIKK family members than the parent compound, e.g. 17 is 60 -fold more potent against DNA-PK than PI3K (p110 $\alpha)$ (Table 2). 


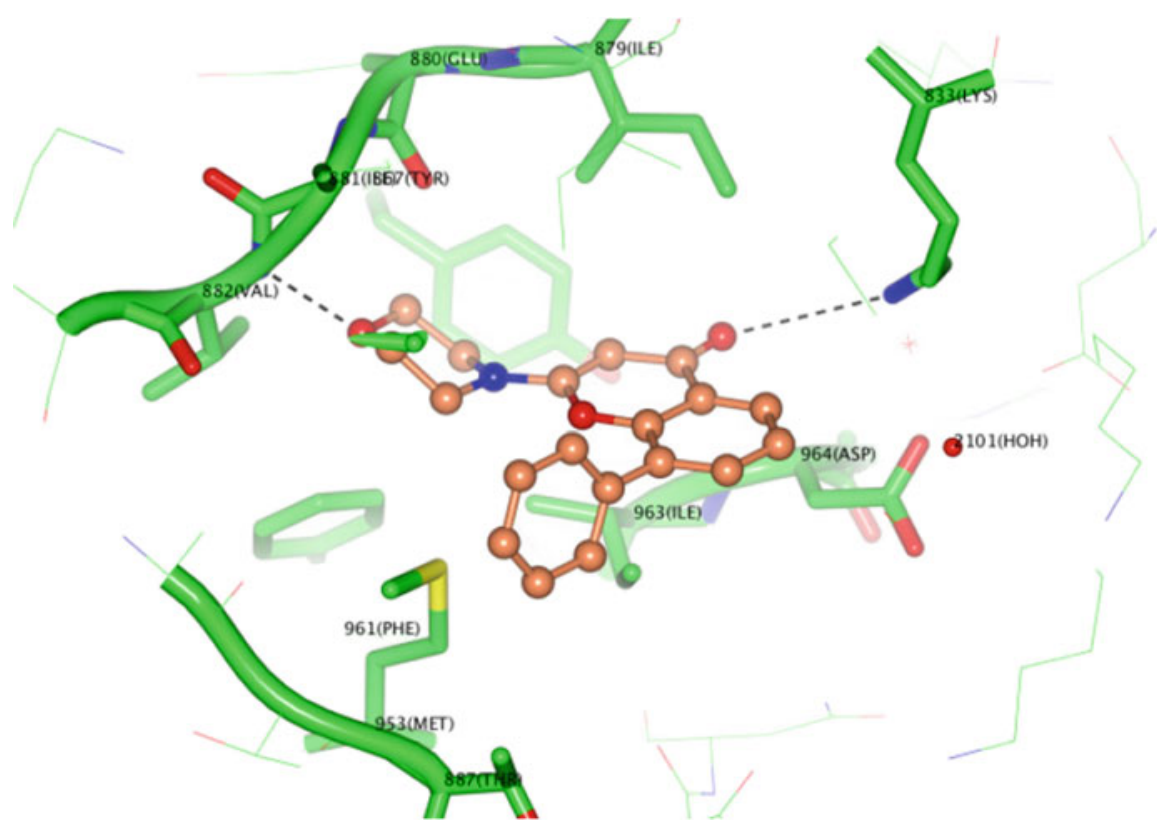

Fig. 7 Crystal structure of LY294002 (13) in complex with the ATP-binding domain of PI3K $\gamma$ [39]

Table 2 Inhibitory activity $\left(\mathrm{IC}_{50} \mu \mathrm{M}\right)$ against different PIKK family members [42]

\begin{tabular}{l|l|l|l|l|l}
\hline & DNA-PK & PI3K $(\mathrm{p} 110 \alpha)$ & ATM & ATR & mTOR \\
\hline $\mathbf{1 7}$ & 0.23 & 13 & $>100$ & $>100$ & 6.2 \\
\hline $\mathbf{1 8}$ & 0.19 & 2.4 & $>100$ & $>100$ & 4.8 \\
\hline $\mathbf{1 9}$ & 0.28 & $>100$ & $>100$ & $>100$ & 5.3 \\
\hline
\end{tabular}<smiles>O=c1cc(N2CCOCC2)oc2c1ccc1ccccc12</smiles>

17<smiles>C[C@H]1CN(c2cc(=O)c3ccc4ccccc4c3o2)CCO1</smiles>

18<smiles>O=c1cc(N2CCOCC2)nc2c3ccccc3ccn12</smiles>

19

Replacement of the chromen-4-one scaffold by the isosteric pyrimidoisoquinolinone structure gave equipotent compounds $\left(\mathbf{1 9} ; \mathrm{IC}_{50}=0.28 \mu \mathrm{M}\right)$ [44]. Several studies have demonstrated that $\mathbf{1 7}$ acts in vitro as a radiosensitiser [45], and as a chemo-potentiator of topoisomerase II poisons in human leukaemia cell lines [46].

A simplification of the chromenone core was attempted with the synthesis of a series of substituted monocyclic pyran-2-one, pyran-4-one, thiopyran-4-one and pyridin-4-one derivatives [47]. The pyran-4-one system and substitution at the pyranone 3- or 5-positions gave a loss of activity. However, library work on 
6-substituted-2-morpholino-pyran-4-one and 6-substituted-2-morpholinothiopyran-4-one led to the identification of 20 (DNA-PK; $\mathrm{IC}_{50}=0.18 \mu \mathrm{M}$ ) and 21 (DNA-PK $\mathrm{IC}_{50}=0.19 \mu \mathrm{M}$ ), both tenfold more potent against DNA-PK than the parent 13 [47, 48].<smiles>O=c1cc(-c2ccc(Cl)cc2)oc(N2CCOCC2)c1</smiles>

20<smiles>O=c1cc(-c2ccc(-c3cccc4ccccc34)cc2)sc(N2CCOCC2)c1</smiles>

21<smiles>O=c1cc(N2CCOCC2)oc2c(-c3cccc(-c4ccccc4)c3)cccc12</smiles>

22

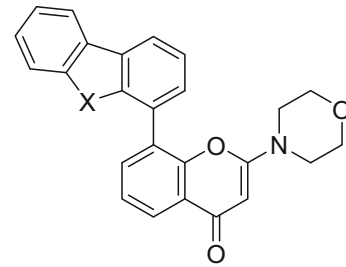

23; $X=O$

$24 ; X=S$<smiles>CCN1CCN(CC(=O)Nc2ccc(-c3cccc4c(=O)cc(N5CCOCC5)oc34)c3sc4ccccc4c23)CC1</smiles>

25

A library of 6-, 7- and 8-substituted chromenones were synthesised using a multi-parallel approach [49]. Interestingly, compound $22\left(\mathrm{DNA}-\mathrm{PK} \mathrm{IC}_{50}=0.11 \mu \mathrm{M}\right)$ showed a tenfold increase in potency compared to $\mathbf{1 3}$, whereas the dibenzofuranyl derivative $(\mathbf{2 3})\left(\mathrm{DNA}-\mathrm{PK} \mathrm{IC}_{50}=0.04 \mu \mathrm{M}\right)$ displayed impressive potency against DNA-PK. The incorporation of a dibenzothiophenyl group led to NU7441 (24), a compound with a 100-fold increase in potency compared with the parent phenyl derivative 13 (DNA-PK IC $_{50}=0.02 \mu \mathrm{M}$ ), along with excellent selectivity over the other PIKK family members (Table 3).

Compound $\mathbf{2 4}$ has been reported to sensitise tumour cells to ionising radiations (Fig. 8a) and increase the effect of etoposide (Fig. 8b) in vitro, indicating a good cellular permeability with a low inherent growth inhibitory activity $[43,50]$. The compound has also been reported to cause doxorubicin-induced DNA DSBs (measured by $\gamma-\mathrm{H} 2 \mathrm{AX}$ foci) to persist and also slightly decrease homologous recombination activity (assessed by Rad51 foci) [51].

An homology model of the ATP-binding site of DNA-PK, derived from the crystal structure of PI3K $\gamma$, was used to guide further inhibitor design [39]. The newly synthesised compounds all possessed polar substituents at the dibenzothiophene 1-position, with an aim to improve physico-chemical properties [52]. Several exhibited high potency against DNA-PK and potentiated the 
Table 3 NU7441 (24) inhibitory activity against different kinases of the PIKK family

\begin{tabular}{l|l|l|l|l|l|l}
\hline & DNA-PK & PI3K & PI4K $_{\beta}$ & ATM & ATR & mTOR \\
\hline $\mathrm{IC}_{50}(\mu \mathrm{M})$ & 0.012 & 5 & 40 & $>100$ & $>100$ & 1.7 \\
\hline
\end{tabular}

A

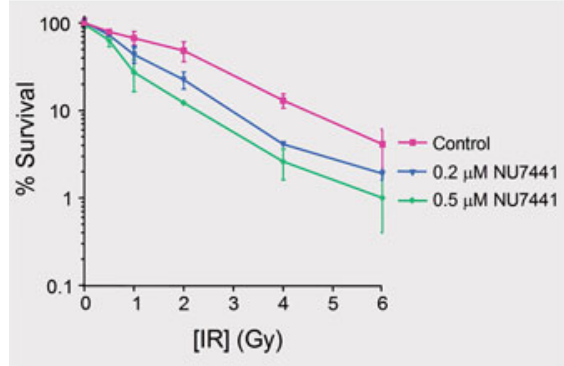

B

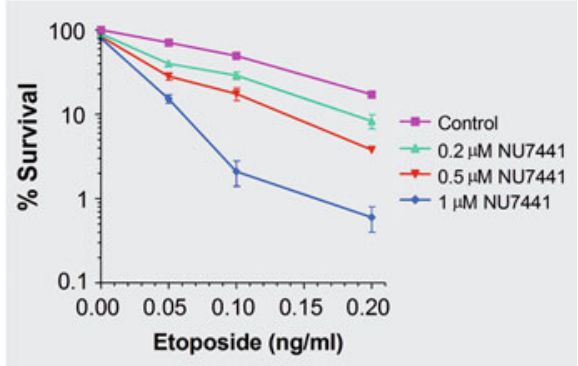

Fig. 8 (a) Radiosensitisation of HeLa cells by NU7441 (24). (b) Enhancement of etoposide cytotoxicity by NU7441 (24) in HeLa cells $[43,50]$

cytotoxicity of ionising radiation (IR) in vitro tenfold or more (e.g. 25; DNA-PK $\mathrm{IC}_{50}=5.0 \pm 1 \mathrm{nM}$, IR dose modification ratio $=13$ ). Furthermore, 25 was shown to potentiate not only IR in vitro but also DNA-inducing cytotoxic anticancer agents, both in vitro and in vivo. Counter-screening against other members of the PIKK family unexpectedly revealed that some of the compounds were potent mixed DNA-PK and PI3K inhibitors [52, 53]. The promising biological activity of $\mathbf{2 5}$ was accompanied by better drug-like properties compared to NU7441 (24), and acceptable plasma protein binding, combined with weak activity against hERG and a panel of CYP450 enzymes [52].

In efforts to optimise the biological and pharmaceutical properties of $\mathbf{2 4}$, and to expand structure-activity relationships (SARs), the core chromenone scaffold and the dibenzothiophen-4-yl moiety have been systematically modified [54, 55]. As 22 is approximately tenfold more potent than the parent 8-phenylchromenone (13), this strongly indicated that the 3-phenyl substituent of $\mathbf{2 2}$ made additional binding interactions within the ATP-binding domain of DNA-PK. By probing this presumed binding interaction further, replacement of the 3-phenyl group of 22 by an isosteric thiophen-2-yl substituent (26) improved DNA-PK inhibitory activity approximately tenfold (DNA-PK; $\mathrm{IC}_{50}=18 \mathrm{nM}$ ) [54]. Subsequent homology modelling studies suggested that the heteroaryl substituent may occupy a putative hydrophobic pocket that could be further exploited, with further SAR resulting in the discovery of $O$-alkoxyphenylchromen-4-one (27) (DNA-PK; $\mathrm{IC}_{50}=8 \mathrm{nM}$ ) $[54,55]$.

Resolvable atropisomeric derivatives of $\mathbf{1 3}$ have also been described. Introduction of a methyl substituent, as a representative example, at the dibenzothiophene 3-position (28) (DNA-PK; $\mathrm{IC}_{50}=1.7 \mu \mathrm{M}$ ) or at the chromenone 7-position (29) (DNA-PK; $\mathrm{IC}_{50}=0.005 \mu \mathrm{M}$ ) of NU7441, generated stable pairs of atropisomers 
Table 4 Inhibition of DNA-PK $\left(\mathrm{IC}_{50} \mu \mathrm{M}\right)$ by 3-substituted dibenzothiophen-4-yl derivatives and 7-substituted chromen-4-one derivatives

\begin{tabular}{l|l|l|l}
\hline & $\mathrm{R}^{1}$ & $\mathrm{R}^{2}$ & DNA-PK inhibition \\
\hline $\mathbf{2 4}$ & $\mathrm{H}$ & $\mathrm{H}$ & 0.03 \\
\hline $\mathbf{2 8}$ & $\mathrm{Me}$ & $\mathrm{H}$ & 1.7 \\
\hline $\mathbf{2 8}-(-)$ & $\mathrm{Me}$ & $\mathrm{H}$ & 1.2 \\
\hline $\mathbf{2 8}-(+)$ & $\mathrm{Me}$ & $\mathrm{H}$ & 100 \\
\hline $\mathbf{2 9}$ & $\mathrm{H}$ & $\mathrm{Me}$ & 0.005 \\
\hline $\mathbf{2 9}-(-)$ & H & $\mathrm{Me}$ & 0.002 \\
\hline $\mathbf{2 9}-(+)$ & H & $\mathrm{Me}$ & 7 \\
\hline
\end{tabular}

due to restricted rotation between the chromen-4-one and dibenzothiophene rings $[56,57]$. Substitution at the dibenzothiophene 3-position $(\mathbf{2 8})$ resulted in an approximately 60-fold reduction in potency of the racemic compound against DNA-PK compared with the parent compound (24). Interestingly, 29 showed a sixfold improvement in potency compared with the parent compound (Table 4).

Following resolution by chiral high-performance liquid chromatography (HPLC), biological evaluation against DNA-PK of each pair of atropisomers showed that DNA-PK inhibitory activity resided exclusively in the (-)-atropisomer ('eutomer') enantiomer, with the antipodal (+)-atropisomer ('distomer') proving inactive at $100 \mu \mathrm{M}[57,58]$.

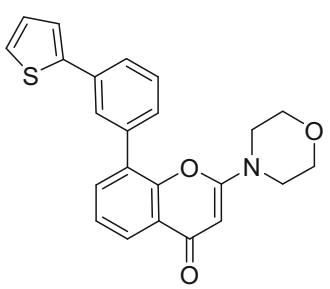

26<smiles>O=C(CN1CCOCC1)Nc1ccc(-c2cccc3c(=O)cc(N4CCOCC4)oc23)cc1OCC1CC1</smiles>

27<smiles>[R]c1ccc2c(=O)cc(N3CCOCC3)oc2c1-c1c([R])ccc2c1sc1ccccc12</smiles>

28; $R^{1}=M e, R^{2}=H$ 29; $R^{1}=H, R^{2}=M e$

Pyridone OK-1035

3-Cyano-5-(4-pyridyl)-6-hydrazonomethyl-2-pyridone, OK-1035 (30), was reported to inhibit DNA-PK activity with an $\mathrm{IC}_{50}$ of $8 \mu \mathrm{M}$ and excellent selectivity (Table 5), appearing at first to be a good candidate for optimisation. However, this proved not to be the case and subsequent structural modifications provided only compounds with inferior potency against DNA-PK [59]. 
Table 5 Inhibition of DNA-PK and various protein kinases by OK-1035 (30)

\begin{tabular}{l|l|l|l|l|l|l|l|l}
\hline & DNA-PK & PKA & PKC & CDK2 & CKI & CKII & MAPK & EGFRK \\
\hline $\mathrm{IC}_{50}(\mu \mathrm{M})$ & 8 & 390 & $>500$ & $>500$ & $>500$ & 420 & $>500$ & $>500$ \\
\hline
\end{tabular}<smiles>N#Cc1cc(-c2ccncc2)c(/C=N/N)[nH]c1=O</smiles>

30

\section{Phenol Related IC Series}

Reported by the ICOS Corporation and Array BioPharma as part of a new series of DNA-PK inhibitors, 2-hydroxy-4-morpholin-4-yl-benzaldehyde (IC60211, $\left.\mathrm{IC}_{50}=400 \mathrm{nM}\right)(\mathbf{3 1})$ is a representative example of DNA-PK inhibitors possessing a morpholine motif. Optimisation of $\mathbf{3 1}$ led to the identification of a number of selective inhibitors (32-36; Table 6), all of which maintain the arylmorpholine substructure [60].<smiles>O=Cc1ccc(N2CCOCC2)cc1O</smiles>

31<smiles>O=C(c1ccc(O)cc1)c1ccc(N2CCOCC2)cc1O</smiles>

34<smiles>CC(=O)c1ccc(N2CCOCC2)cc1O</smiles>

32<smiles>O=c1cc(-c2ccccc2)oc2cc(N3CCOCC3)cc(O)c12</smiles>

35<smiles>O=C(CO)c1ccc(N2CCOCC2)cc1O</smiles>

33<smiles>O=c1c2ccccc2[nH]c2cc(N3CCOCC3)cc(O)c12</smiles>

36

Compounds 32-34 have been reported to inhibit DNA DSB repair in cells not only as single agents but also in combination with chemotherapy and radiotherapy [61]. In vivo efficacy has also been demonstrated in combination studies using ionising radiation [62]. The small-molecule DNA-PK inhibitor 36 was found to synergise with 7-ethyl-10-hydroxy-camptothecin (SN38), to enhance killing of colon cancer cells in vitro. Compound $\mathbf{3 6}$ is relatively non-toxic, with an $\mathrm{IC}_{50}$ of $29 \mu \mathrm{M}$ in both HCT-116 and HT-29 cell lines. Significant reductions in the $\mathrm{IC}_{50}$ 
Table 6 Inhibitory activity $\left(\mathrm{IC}_{50} \mathrm{nM}\right)$ of representative DNA-PK inhibitors against various PI3Ks [60]

\begin{tabular}{l|l|r|r|r|r}
\hline & DNA-PK & \multicolumn{1}{c|}{$1_{110_{\alpha}}$} & $\mathrm{p} 110_{\beta}$ & $\mathrm{p} 110_{\delta}$ & \multicolumn{1}{c}{$\mathrm{p} 110_{\gamma}$} \\
\hline 31 & 400 & 10,000 & 2,800 & 5,100 & 37,000 \\
\hline 32 & 120 & 1,400 & 135 & 880 & 1,000 \\
\hline 33 & 44 & 890 & 42 & 490 & 180 \\
\hline 34 & 35 & 2,700 & 400 & 1,800 & 5,000 \\
\hline 35 & 34 & 3,800 & 1,700 & 2,800 & 7,900 \\
\hline
\end{tabular}

values of SN38 were detected at 5 and $10 \mu \mathrm{M}$ of inhibitor [51]. Additionally, 36 can synergistically sensitise three genetically diverse breast cancer cell lines to doxorubicin and cisplatin [63]. Improved cytotoxicity and significant synergy were observed with the topoisomerase II inhibitor, doxorubicin or cisplatin in the presence of non-toxic concentrations of 36. Furthermore, 36 was shown to decrease doxorubicin-induced DNA-PKcs autophosphorylation on Ser2056 and increase doxorubicin-induced DNA fragmentation [64].

\section{SU11752}

In an effort to develop a specific DNA-PK inhibitor, Sugen undertook a screening campaign of 3-substituted indolin-2-ones and successfully identified the ATP-competitive DNA-PK inhibitor SU11752 (37). Interestingly, the compound showed good potency against DNA-PK $\left(\mathrm{IC}_{50}=0.13 \pm 0.028 \mu \mathrm{M}\right)$ combined with selectivity over PI3K $\left(\mathrm{p} 110 \gamma ; \mathrm{IC}_{50}=1.10 \mu \mathrm{M}\right)$ [40, 65]. The compound was also reported as a poor inhibitor of ATM kinase activity in cells [65].

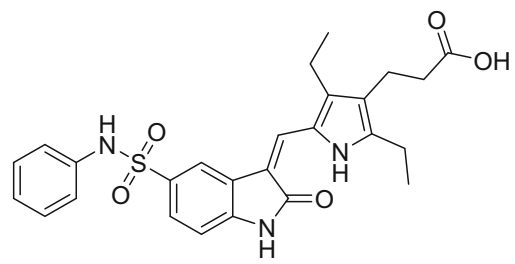

37

\section{Vertex}

In a patent published by Vertex Pharmaceuticals, 251 of the compounds described had a $K_{i}$ of less than $0.1 \mu \mathrm{M}$ for the inhibition of DNA-PK [66]. More recently, it has been disclosed that VX-984 (38) is a DNA-PK inhibitor currently undergoing a phase I clinical study, in combination with pegylated liposomal doxorubicin in patients with advanced solid tumours or lymphomas. 


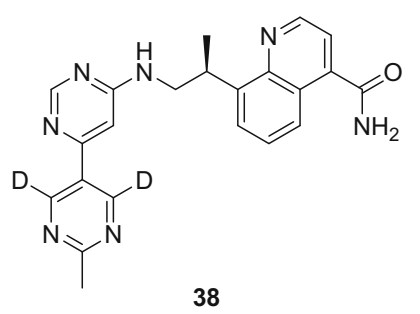

Compound 38 is reported to have an $\mathrm{IC}_{50}$ of $88 \pm 64 \mathrm{nM}$ for inhibition of DNA-PKcs autophosphorylation (Ser2056) in A549 lung cancer cells, with good selectivity versus other PI3K family members [67].

\subsection{Ataxia-Telangiectasia Mutated Kinase}

\subsubsection{Structural Features of Ataxia-Telangiectasia Mutated Kinase}

The ATM gene codes for a $350 \mathrm{kDa}$ protein, consisting of 3,056 amino acids. Characteristic for ATM are five domains: from the $\mathrm{N}$-terminus to C-terminus these are the HEAT repeat domain, the FAT domain, the kinase domain (KD), the PIKKregulatory domain (PRD) and the FAT-C-terminal (FATC) domain. The FAT domain interacts with the kinase domain of ATM to stabilise the C-terminal region. The KD effects kinase activity, whilst the PRD and the FATC domain regulate it. Although no structure for ATM has been solved, the overall shape of ATM is envisaged to be very similar to DNA-PKcs, comprised of a head and a long arm, which wraps around double-stranded DNA after a conformational change. The entire $\mathrm{N}$-terminal domain, together with the FAT domain, is predicted to adopt an $\alpha$-helical structure. This $\alpha$-helical structure is believed to form a tertiary structure, which has a curved, tubular shape. FATC is the C-terminal domain with a length of about 30 amino acids. It is highly conserved and consists of an $\alpha$-helix followed by a sharp turn, which is stabilised by a disulfide bond [68].

\subsubsection{Ataxia-Telangiectasia Mutated Kinase and the Repair Pathway}

ATM is one of the best known PIKK members. The absence of this protein is characteristic of a neurodegenerative disorder termed ataxia-telangiectasia, which involves a high sensitivity to ionising radiation, neurodegeneration and immunodeficiency [69]. ATM has the main function of regulating the G1/S and G2/M cell cycle checkpoints in response to DSBs, preventing progression of the cell cycle when DNA is damaged. The cascade mechanism involves activation of tumour suppressor protein p53 via phosphorylation [70], which stimulates the transcription 
of $\mathrm{p} 21$ protein and interacts with $\mathrm{CDK} 2 / \mathrm{Cyclin} \mathrm{E}$ halting progression of the cycle from G1 to $S$ phase and allowing DNA repair [71]. Another pathway of interaction between ATM and p53 involves activation of CHK2 protein kinase by ATM [72]. CHK2 obstructs the p53-MDM2 interaction by phosphorylation of p53, leading to arrest of the cell cycle. In addition, ATM also directly phosphorylates MDM2 (Ser395), altering its interaction with p53. These pathways act via ATM to halt cell cycle progression in response to DNA damage [73]. Thus, the main role of ATM is the detection of DNA damage, being itself an important component of the NHEJ pathway [74].

\subsubsection{Ataxia-Telangiectasia Mutated Kinase Inhibitors}

Although ATM has attracted considerable interest as a therapeutic target, very few useful inhibitors with potent activity have been reported. Many of the known inhibitors of ATM, including wortmannin (12) $\left(\mathrm{IC}_{50}=150 \mathrm{nM}\right)$ and caffeine (39) $\left(\mathrm{IC}_{50}=200 \mu \mathrm{M}\right)$, lack specificity, hence inhibiting a wide range of PIKKs [75].
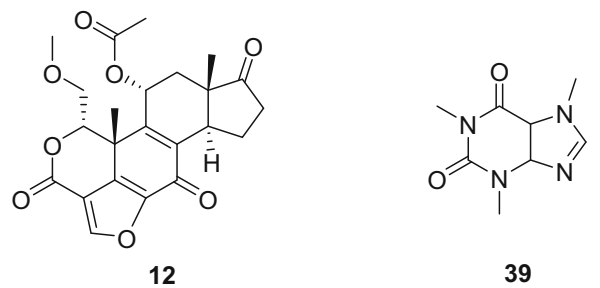

\section{KU-55933, KU-60019 and KU-59403}

Important inhibitors were developed by screening of combinatorial libraries around the structure of LY294002 (13). The KuDOS Pharmaceuticals-Newcastle group identified weak ATM-inhibitory activity within a pyran-4-one series (exemplified by 40), which prompted further chemical library generation based on this scaffold [47]. Replacing the 4-methoxyphenyl group of $\mathbf{4 0}$ resulted in the identification of 41, a highly selective inhibitor of ATM. Compound 41 has an $\mathrm{IC}_{50}$ of $13 \mathrm{nM}$ and $K_{i}$ of $2.2 \mathrm{nM}$, with marked sensitisation of cancer cells to IR and topoisomerase II inhibitors in vitro $[47,76]$. 
<smiles>O=c1cc(N2CCOCC2)oc2c(-c3ccccc3)cccc12</smiles>

13<smiles>COc1ccc(-c2cc(=O)cc(N3CCOCC3)o2)cc1</smiles>

40<smiles>O=c1cc(-c2cccc3c2Sc2ccccc2S3)oc(N2CCOCC2)c1</smiles>

41<smiles>C[C@H]1CN(CC(=O)Nc2ccc3c(c2)Cc2cccc(-c4cc(=O)cc(N5CCOCC5)o4)c2S3)C[C@@H](C)O1</smiles>

42<smiles>CN1CCN(CCC(=O)Nc2ccc3c(c2)Sc2cccc(-c4cc(=O)cc(N5CCOCC5)o4)c2S3)CC1</smiles>

Modification of the thianthrene substituent of $\mathbf{4 1}$ was investigated, but minor structural changes were commonly detrimental to activity. An improved watersoluble analogue 42, included a 2,6-dimethylmorpholin-4-yl group at position 2 on thioxanthene, leading to potent ATM-inhibitory activity $\left(\mathrm{IC}_{50}=6.3 \mathrm{nM}\right)$, a twofold improvement in ATM inhibition over 41. Combining potency, cellular activity (enhancement ratios of 2.1-2.9 at $0.6 \mu \mathrm{M}$ ) and pharmacokinetics, 42 was proven to be highly selective with limited toxicity towards healthy cells. It was shown to inhibit the DDR and reduce AKT phosphorylation and prosurvival signalling. Inhibition of migration and invasion was also reported, along with effective radiosensitisation of human glioma cells [76, 77]. A further analogue KU-59403 (43) showed improved potency over 41 (Table 7), as well as improved solubility and bioavailability, allowing for in vivo studies and advanced preclinical evaluation. Compound $\mathbf{4 1}$ is without intrinsic cytotoxicity but is a potent enhancer of topoisomerase I and II poison cytotoxicity in vitro and was shown to increase the efficacy of topoisomerase I and II poisons in vivo without intrinsic toxicity despite normal tissue exposure [78].

\section{CP466722}

Identified by Pfizer from a targeted library screening campaign, CP466722 (44) is a highly selective and rapidly reversible ATM inhibitor that does not inhibit other PIKK family members or PI3K in a cellular setting [79]. 
Table 7 Inhibition of ATM and related kinase activity by LY294002 (13), KU55933 (41) and KU59403 (43) [78]

\begin{tabular}{l|l|l|l|l|l|l}
\hline \multirow{2}{*}{} & \multicolumn{6}{|l}{ Enzyme $\mathrm{IC}_{50}, \mu \mathrm{mol} / \mathrm{L}$} \\
\cline { 2 - 7 } & ATM & DNA-PK & PI3K & ATR & PI4K & mTOR \\
\hline 13 & $>100$ & 1.5 & 2 & 100 & ND & 3 \\
\hline 41 & 0.013 & 2.5 & 1.7 & $>10$ & $>10$ & 9.3 \\
\hline 43 & 0.003 & 9.1 & 10 & $>100$ & $>10$ & 14 \\
\hline
\end{tabular}<smiles>COc1cc2ncnc(-n3nc(-c4ccccn4)nc3N)c2cc1OC</smiles>

It has been shown in clonogenic survival assays to be sufficient to sensitise cells to IR and suggests that therapeutic radiosensitisation may only require ATM inhibition for short periods of time. Transient exposure of tumour cells to 44 inhibits ATM adequately to enhance the cell's sensitivity to irradiation. After compound washout, the inhibition was rapidly and completely reversed, suggesting that a treatment with a minimal dose of $\mathbf{4 4}$ for brief periods may achieve a maximum therapeutic effect [79].

\section{3-Quinoline Carboxamides}

A novel series of 3-quinoline carboxamides was recently identified at AstraZeneca through a direct screening approach [80]. Initial screening hit $\mathbf{4 5}$ was a submicromolar inhibitor of ATM $\left(\mathrm{IC}_{50}=0.008 \mu \mathrm{M}\right)$, displaying promising selectivity over other PIKKs and PI3K isoforms ( $>$ tenfold against DNA-PK and $>400$ fold against mTOR). Compound 46 exhibited a tenfold improvement in potency $\left(\mathrm{IC}_{50}=0.073 \mu \mathrm{M}\right)$ over 45 , along with increased selectivity over ATR. 
<smiles>CCC(CC)CNc1c(C(N)=O)cnc2ccc(C#N)cc12</smiles>

45

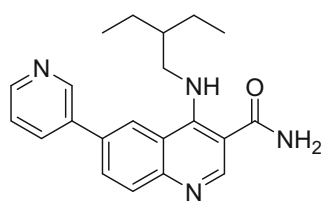

46<smiles>CCC(CC)CNc1c(C(N)=O)cnc2ccc(-c3ccc(COC)nc3)cc12</smiles>

47<smiles>COCc1ccc(-c2ccc3ncc(C(N)=O)c(N[C@H](C)C4CCOCC4)c3c2)cn1</smiles>

48

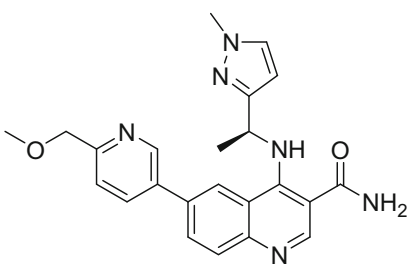

49

Subsequent investigation at the $\mathrm{C} 4$ position did not provide any significant improvement but rather gave vital insight into the how the nature of substituents could influence pharmacokinetic profiles and selectivity. Investigation at C6 was carried out in parallel, whereby it was discovered that $p$-substituted analogue 47 exhibited improved potency $\left(\mathrm{IC}_{50}=0.045 \mu \mathrm{M}\right)$ and kinase selectivity. Extensive SAR at each position on the quinoline core allowed the rapid discovery of optimum combinations and resulted in the finding of $48\left(\mathrm{IC}_{50}=0.046 \mu \mathrm{M}\right)$ and 49 $\left(\mathrm{IC}_{50}=0.033 \mu \mathrm{M}\right)$ as potent and highly selective ATM inhibitors, with overall absorption, distribution, metabolism and excretion (ADME) properties suitable for oral dosing. In combination with the DSB-inducing agent irinotecan, significant tumour volume reductions were observed in an SW620 colorectal cancer xenograft model [80].

\subsection{Ataxia-Telangiectasia and Rad3-Related Kinase}

\subsubsection{Structural Features of Ataxia-Telangiectasia and Rad3-Related Kinase}

ATR (human AT and Rad3 related) is a large kinase comprising 2,644 amino acids, with a molecular weight of $300 \mathrm{kDa}$. ATR-interacting protein (ATRIP) is the $85 \mathrm{kDa}$ binding partner of ATR, which binds to the N-terminus to promote localisation to sites of replication stress [81]. There are no recognised differences in the phenotypes that result from the loss of ATR or ATRIP, which suggests that ATRIP should be considered a subunit of ATR holoenzyme [82]. 
Fig. 9 Cascade pathways initiated by ataxiatelangiectasia mutated (ATM) and ataxiatelangiectasia and Rad3related (ATR) kinase

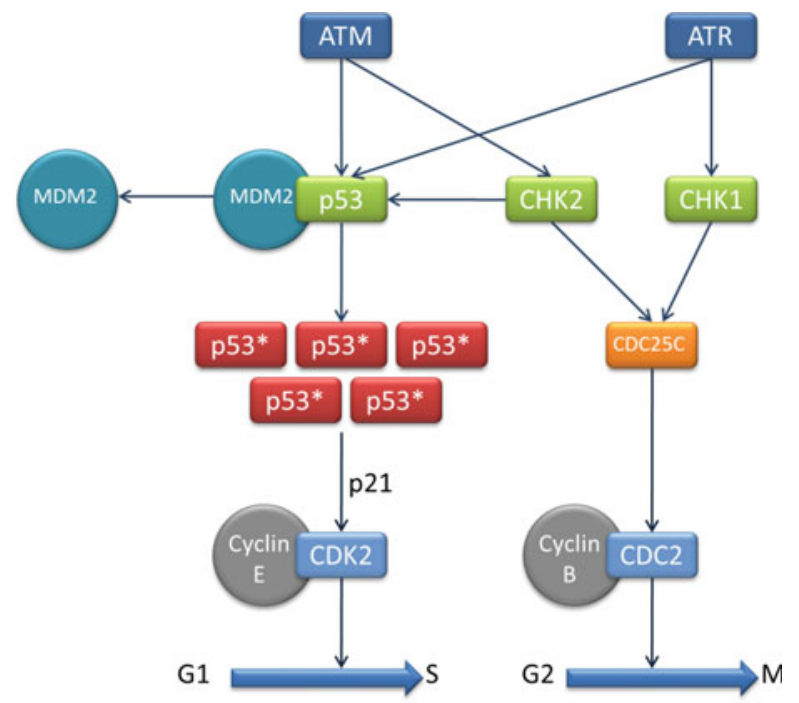

\subsubsection{Ataxia-Telangiectasia and Rad3-Related Kinase and the Repair Pathway}

ATR is a member of the PIKK family closer in size and function to ATM, and sharing around $60 \%$ of the kinase domain. This similarity is reflected by a degree of overlapping function between the two kinases (Fig. 9) [73]. ATR has shown ability to phosphorylate p53 on Ser15 in vitro [83] and in vivo [84] similar to ATM. However, ATR phosphorylation responds mainly to DNA damage induced by UV radiation and has a faster response to DNA damage. It is believed that ATR is responsible for maintaining the phosphorylated state of the targets p53, murine double minute 2 (MDM2) and CHK2 [84]. ATR is also involved in a pathway initiated by phosphorylation of checkpoint kinase 1 (CHK1) kinase (Ser345) [85].

\subsubsection{Ataxia-Telangiectasia and Rad3-Related Kinase Small-Molecule Inhibitors}

Research on inhibitors of ATR (ATRis) has been on-going for more than a decade, with the first small-molecule inhibitors identified in the late 1990s. Despite this, novel patented data has only been disclosed from 2009 onwards, with the first report on ATR-selective small-molecule inhibitors published in 2009 [86]. In 2006, Knight et al. conducted a study in which a chemically diverse set of PI3K inhibitors in preclinical development were screened against several lipid kinases. Compounds 50-55 were identified as moderate ATRis in an enzymatic assay (ATR IC Fo $_{2}$ 0.85-21 $\mu \mathrm{M}$ ), but with no selectivity over DNA-PK or ATM [87]. In the same study, LY294002 (13), originally developed as a PI3K inhibitor [41], but later 
recognised as a pan-inhibitor of the PIKK family [88, 89], was determined to be inactive $\left(\mathrm{ATR} \mathrm{IC}_{50}=>100 \mu \mathrm{M}\right)[87]$.<smiles>Oc1cccc(-c2nc(N3CCOCC3)c3oc4ncccc4c3n2)c1</smiles><smiles>CC(=O)NC1NC(C)=C(c2ccc(Cl)c(S(=O)(=O)NCCO)c2)S1</smiles>

53<smiles>Oc1cccc(-c2nc(N3CCOCC3)c3oc4ncccc4c3n2)c1</smiles><smiles>O=C1NC(=S)S/C1=C/c1ccc2c(c1)N(Cc1ccc(F)c(Cl)c1)C(=O)CO2</smiles>

54<smiles>COc1ccc2c(c1OC)N=C(NC(=O)c1cccnc1)N1CCN=C21</smiles><smiles>O=c1cc(-c2cccc3c2Sc2ccccc2S3)oc(N2CCOCC2)c1</smiles>

Wortmannin and Caffeine

The fungal metabolite wortmannin (12) is an irreversible pan-inhibitor of the PIKK family but has relatively weak ATR activity $\left(\mathrm{ATR} \mathrm{IC}_{50}=1.8 \mu \mathrm{M}\right.$, ATM $\mathrm{IC}_{50}=150 \mathrm{nM}$ and DNA-PK $\mathrm{IC}_{50}=16 \mathrm{nM}$ ). It has been proposed that the radiosensitising effect is perhaps due to the inhibition of DNA-PK kinase activity rather than ATR inhibition [90].

Similarly, caffeine (39) has been recognised as a weak pan-PIKK inhibitor (ATR $\mathrm{IC}_{50}=1.1 \mathrm{mM}$, ATM IC $\mathrm{IC}_{50}=0.2 \mathrm{mM}$ and DNA-PK $\mathrm{IC}_{50}=10 \mathrm{mM}$ ), with the radiosensitising effect attributed to both ATR and ATM kinases [91].

\section{Schisandrin B}

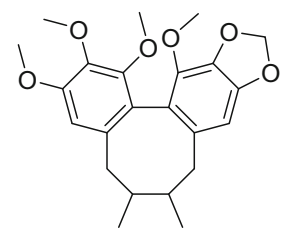

56 
In 2007, Nishida et al. filed a patent which revealed the dibenzocyclooctadiene lignans schisandrins and gomisins as the first ATR-selective small-molecule inhibitors [92]. One of the compounds of interest, Schisandrin B (56), is a naturally occurring dibenzocyclooctadiene lignin found in Schisandra chinensis, a medicinal herb. It was demonstrated that Schisandrin B was able to abolish UV-induced intraS-phase and G2/M cell cycle checkpoints and increase the cytotoxicity of UV radiation in human lung cancer cells (A549 adenocarcinoma). Furthermore, Schisandrin B was found to inhibit p53 and CHK1 ATR-dependent phosphorylation but did not prevent ATR-activating association to the ATRIP. It is selective for ATR kinase activity in vitro $\left(\mathrm{IC}_{50}=7.25 \mu \mathrm{M}\right)$, but due to the weak inhibitory potency against ATR, high drug concentrations ( $30 \mu \mathrm{M}$ for cellular assays) were necessary [86].

\section{Torin 2}

Torin 2 (57) was described in 2013 as a potent ATP-competitive inhibitor of ATM and ATR $\left(\right.$ ATM IC $50=<0.01 \mu \mathrm{M}$, ATR IC $\left._{50}=<0.01 \mu \mathrm{M}\right)$ [93].

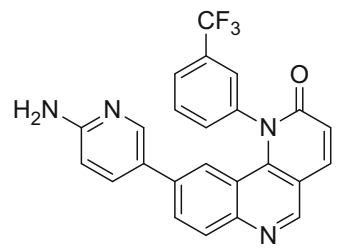

57

Torin 2 inhibited the cellular activity of the ATR kinase, as assessed by phosphorylation status of $\mathrm{CHK}^{\mathrm{S} 317}$ following exposure of HCT116 colon cancer cells to UV-induced DNA damage [94, 95].

\section{ETP-46464}

Researchers at the Spanish National Cancer Research Centre screened a collection of 623 PI3K inhibitors, aiming to find hits against the PI3KK family, specifically ATR [96]. Following a high-throughput microscopy screen, ETP-46464 (58), was identified as an encouraging hit, which potently inhibited ATR in vitro $\left(\mathrm{IC}_{50}=14 \mathrm{nM}\right)$ and showed some selectivity over ATM. ETP-46464 suffers from poor pharmacological properties in mice, halting development. 


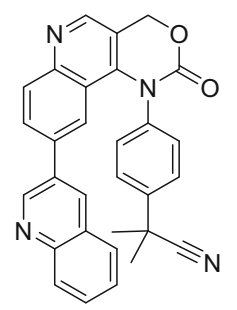

58

\section{NU6027}

In 2001, a more potent ATR inhibitor, NU6027 (59) $\left(\mathrm{IC}_{50}=0.1 \mu \mathrm{M}\right)$, was reported to sensitise several breast and ovarian cancer cell lines to IR and several chemotherapeutic agents [97].

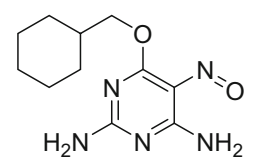

59

As 59 was originally developed as a CDK2 inhibitor $\left(\mathrm{IC}_{50}=2.2 \mu \mathrm{M}\right)$, it was found to be a non-selective inhibitor. Compound $\mathbf{5 9}$ was synergistic with the PARP inhibitor rucaparib, in MCF7 cells and synthetically lethal in XRCC1-defective EM9 cells, confirming that impaired DNA SSB repair is synthetically lethal with ATR inhibition.

\section{NVP-BEZ235}

In 2011, Toledo et al. reported the results of a cell-based compound library screening approach for the identification of potent ATR inhibitors [94]. One of the compounds identified to possess significant inhibitory against ATR kinase was NVP-BEZ235 (60) (ATR, ATM, DNA-PK IC $_{50}<21 \mathrm{nM}$ ), a drug originally revealed by Novartis [98] as a highly potent PI3K/mTOR inhibitor. 


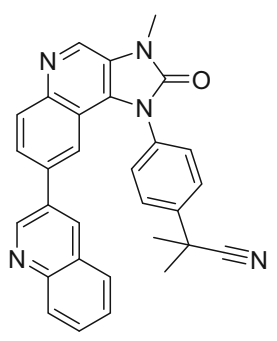

60

NVP-BEZ235 inhibited ionising radiation-induced ATM, CHK1, CHK2 and DNA-PK phosphorylation and affected ionising radiation-induced $\gamma \mathrm{H} 2 \mathrm{AX}$ formation. NVP-BEZ235 was, at the time of writing, undergoing clinical trials for solid tumours.

\section{WYC02 and WYC0209}

WYC02 (61) is a flavonoid isolated and identified from the whole plant extract of Thelypteris torresiana, a fern species native to Taiwan.<smiles>O=C1C=CC(O)(c2cc(=O)c3c(O)cc(O)cc3o2)C=C1</smiles>

61<smiles>O=C1C=CC(O)(c2cc(=O)c3ccccc3o2)C=C1</smiles>

62

The natural compound $\mathbf{6 1}$ and its more potent synthetic analogue WYC0209 (62) have been shown to inhibit ATR-mediated CHK1 phosphorylation, impair the G2/M checkpoint and improve cancer sensitivity to cisplatin [99]. Further studies showed that 62 inhibits ATR kinase activity at least four times greater than 61 [100].

\section{AZD6738}

Another ATR inhibitor with excellent drug metabolism and pharmacokinetic (DMPK) properties currently in clinical development is the AstraZeneca inhibitor AZD6738 (63). Initial hit (64) was identified as a potent ATRi from a screening campaign (cellular $\mathrm{IC}_{50}=1.1 \mathrm{nM}$ ), with high selectivity against other PIKK and PI3K kinases. 


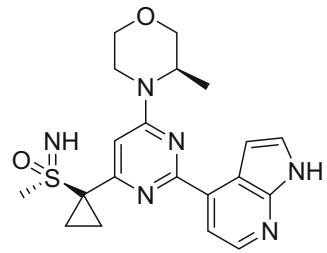

63

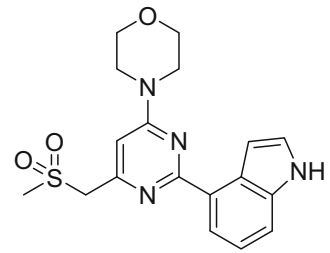

64

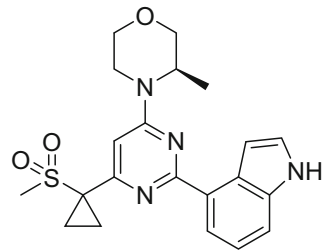

65

Optimisation from the superior screening hit 64 within tight SAR space enabled the discovery of $\mathbf{6 5}$, a potent and selective ATR inhibitor which has been shown to possess substantial in vivo single agent activity in MRE11A-deficient cancer cells at well-tolerated doses [101, 102]. Compound $\mathbf{6 5}$ had poor aqueous solubility but displayed high Caco-2 permeability and good stability in rat hepatocytes, leading to satisfactory bioavailability in a rat PK study. In contrast to 65, 63 incorporates a structural change, whereby a sulfoximine replaced the methyl sulfone as a rational attempt to improve solubility. As a result, 63 has notably improved solubility, bioavailability, pharmacokinetics and pharmacodynamics and is suitable for oral dosing [103]. It acts to inhibit phosphorylation of the ATR downstream target CHK1, whilst increasing phosphorylation of the DNA DSB marker $\gamma \mathrm{H} 2 \mathrm{AX}$ in vitro. It significantly increases antitumour activity of IR or carboplatin in vivo $[103,104]$. A phase I clinical trial to assess the safety of AZD6738 alone and in combination with radiotherapy in patients with solid tumours was underway at the time of writing.

\section{VE-821}

A high-throughput screening campaign led to the discovery of the first series of both potent and selective ATR kinase inhibitors by Vertex Pharmaceuticals. The compounds generally featured a central 2-aminopyrazine core. Compounds that lacked the 2-amino group resulted in higher enzymatic ATR $K_{i}$ values [105].<smiles>Nc1ncc(-c2ccccc2)nc1C(=O)Nc1ccccc1</smiles>

66

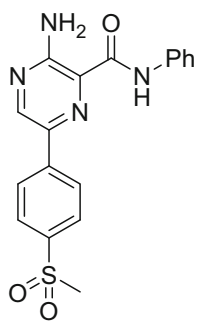

67<smiles>CC(CN(C)C)S(=O)(=O)c1ccc(-c2cnc(N)c(C(=O)Nc3ccccc3)n2)cc1</smiles>

68 
Pyrazine derivative (66) was a promising ATP-competitive hit (ATR; $\mathrm{IC}_{50}=0.62 \mu \mathrm{M}$ ), with excellent selectivity over DNA-PK and ATM [106]. The suboptimal potency and cellular activity was addressed by further SAR, guided by homology modelling of the ATP-binding domain of ATR. The pyrazine N1 serves as the hydrogen bond acceptor group for the interaction with the backbone $\mathrm{NH}$ of Val2378, and the adjacent 2-amino group donates a hydrogen bond to the carbonyl of Glu2380 [107].

The introduction of a 4-sulfonyl group $(67)\left(\mathrm{IC}_{50}=26 \mathrm{nM}\right)$ increased the potency and selectivity, attributed to a favourable interaction between the sulfone oxygen and the $\mathrm{NH}$ of the ATR-specific residue Gly2385. Compound $\mathbf{6 7}$ was shown to be a potent ATP-competitive inhibitor of ATR $\left(K_{i}=13 \mathrm{nM}\right)$ with good selectivity over a panel of the related PIKKs, ATM, DNA-PKcs and mTOR [106]. It inhibited phosphorylation of the ATR downstream target CHK1 at Ser345 and showed strong synergy with genotoxic agents from multiple classes in the colorectal cancer cell line HCT116. The observed chemo-sensitisation was most pronounced with DNA cross-linking agents such as cisplatin and carboplatin and was further enhanced by knockdown of p53 expression, in ATM-deficient cells or in combination with the specific ATM inhibitor KU-55933 (41) (see Sect. 3.2.3). Significantly, the cytotoxicity of $\mathbf{6 7}$ in normal cells appeared minimal, causing only a reversible growth arrest without significant induction of cell death [106].

Further optimisation of $\mathbf{6 7}$ led to compound $\mathbf{6 8}$, which was selected for in-depth biological evaluation. Compound $\mathbf{6 8}$ combines potent ATP-competitive ATR-inhibitory activity $\left(K_{i}=6 \mathrm{nM}\right)$ and excellent cellular activity. It also possesses good physico-chemical properties, including aqueous solubility, cell permeability and minimal efflux.

\section{VE-822/VX-970}

VE-822 (69) is an analogue of $\mathbf{6 7}$, which possesses increased potency and selectivity against ATR. It also benefits from increased solubility and good pharmacokinetic properties.

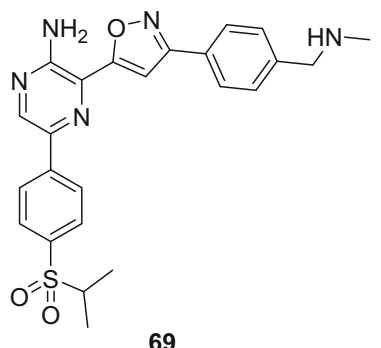


It was shown to potently radiosensitise pancreatic cancer cell lines in vitro. Additionally, treatment with 69 profoundly radiosensitised xenograft models of human pancreatic cancer and further increased the growth delay induced by IR combined with gemcitabine. Crucially, $\mathbf{6 9}$ was well tolerated in mice and did not enhance toxicity in normal cells and tissues [108]. The compound is now known as VX-970 and was the first selective ATR inhibitor to enter clinical trial development. In 2014, Vertex Pharmaceuticals published a study in which it was shown to markedly sensitise a panel of non-small cell lung cancer cell lines, but not normal cells, to multiple DNA-damaging drugs, namely cisplatin, oxaliplatin, gemcitabine and etoposide [109]. The data suggested that VX-970 may have the potential to increase the efficacy of DNA-damaging therapy in patients with lung cancer. The safety, tolerability and pharmacokinetics were, at the time of writing, being assessed in a phase I clinical trial. The strategy was to evaluate VX-970 in early stage trials in selected tumour types and patient subtypes that are expected to be responsive to ATR inhibition based on biomarker data. It is expected to be evaluated as monotherapy and in combination with other cancer therapies, including PARP inhibitors and other targeted agents, chemotherapy and radiotherapy.

\section{References}

1. Jackson SP, Bartek J (2009) The DNA-damage response in human biology and disease. Nature 461:1071-1078

2. Hoeijmakers JHJ (2001) Genome maintenance mechanisms for preventing cancer. Nature 411(6835):366-374

3. De Bont R, van Larebeke N (2004) Endogenous DNA damage in humans: a review of quantitative data. Mutagenesis 19(3):169-185

4. Sibanda BLD, Chirgadze DY, Blundell TL (2010) Crystal structure of DNA-PKcs reveals a large open-ring cradle comprised of HEAT repeats. Nature 463(1277):118-121

5. Deans AJ, West SC (2011) DNA interstrand crosslink repair and cancer. Nat Rev Cancer 11 (7):467-480

6. Schärer OD (2003) Chemistry and biology of DNA repair. Angew Chem Int Ed 42 (26):2946-2974

7. Pogozelski WK, Tullius TD (1998) Oxidative strand scission of nucleic acids: routes initiated by hydrogen abstraction from the sugar moiety. Chem Rev 98(3):1089-1108

8. Pâques F, Haber JE (1999) Multiple pathways of recombination induced by double-strand breaks in Saccharomyces cerevisiae. Microbiol Mol Biol Rev 63(2):349-404

9. Nakamura J, Walker VE, Upton PB, Chiang S-Y, Kow YW, Swenberg JA (1998) Highly sensitive apurinic/apyrimidinic site assay can detect spontaneous and chemically induced depurination under physiological conditions. Cancer Res 58(2):222-225

10. Loeb LA, Preston BD (1986) Mutagenesis by apurinic/apyrimidinic sites. Annu Rev Genet 20 (1):201-230

11. Robertson AB, Klungland A, Rognes T, Leiros I (2009) DNA repair in mammalian cells. Cell Mol Life Sci 66(6):981-993

12. Odell ID, Wallace SS, Pederson DS (2013) Rules of engagement for base excision repair in chromatin. J Cell Physiol 228(2):258-266

13. Furgason JM, Bahassi EM (2013) Targeting DNA repair mechanisms in cancer. Pharmacol Ther 137(3):298-308 
14. Nouspikel T (2009) Nucleotide excision repair: variations on versatility. Cell Mol Life Sci 66 (6):994-1009

15. Iyer RR, Pluciennik A, Burdett V, Modrich PL (2005) DNA mismatch repair: functions and mechanisms. Chem Rev 106(2):302-323

16. Khanna KK, Jackson SP (2001) DNA-double-strand breaks: signalling, repair and the cancer connection. Nat Genet 27:247-254

17. Christmann M, Tomicic MT, Roos WP, Kaina B (2003) Mechanisms of human DNA repair: an update. Toxicology 193:3-34

18. Collis SP, DeWeese TL, Jeggo PA, Parker AR (2005) The life and death of DNA-PK. Oncogene 24:949-961

19. Shiloh Y (2006) The ATM-mediated DNA-damage response: taking shape. Trends Biochem Sci 31:402-410

20. Petrini JH (2000) The Mre11 complex and ATM: collaborating to navigate S phase. Curr Opin Cell Biol 12:293-296

21. Sancar A, Lindsey-Boltz LA, Unsal-Kacmaz K, Linn S (2004) Molecular mechanisms of mammalian DNA repair and the DNA damage checkpoints. Annu Rev Biochem 73:39-85

22. West SC (2003) Molecular views of recombination proteins and their control. Nat Rev Mol Cell Biol 4:435-445

23. Finlay MRV, Griffin RJ (2012) Modulation of DNA repair by pharmacological inhibitors of the PIKK protein kinase family. Bioorg Med Chem Lett 22(17):5352-5359

24. Ma C-C, Li H, Wan R-Z, Liu Z-P (2014) Developments of DNA-dependent protein kinase inhibitors as anticancer agents. Mini-Rev Med Chem 14:884-895

25. Shiloh Y (2003) ATM and related protein kinases: safeguarding genome integrity. Nat Rev Cancer 3(3):155-168

26. Grimson A, O'Connor S, Newman CL, Anderson P (2004) SMG-1 is a phosphatidylinositol kinase-related protein kinase required for nonsense-mediated mRNA decay in Caenorhabditis elegans. Mol Cell Biol 24(17):7483-7490

27. Laplante M, Sabatini DM (2012) mTOR signaling in growth control and disease. Cell 149 (2):274-293

28. Downs JA, Jackson SP (2004) A means to a DNA end: the many roles of Ku. Nat Rev Mol Cell Biol 5:367-378

29. Neal JA, Meek K (2011) Choosing the right path: does DNA-PK help make the decision? Mutat Res-Fund Mol M 711(1-2):73-86

30. Walker JR, Corpina RA, Goldberg J (2001) Structure of the Ku heterodimer bound to DNA and its implications for double-strand break repair. Nature 412:607-614

31. Hammel M, Yu Y, Mahaney BL, Cai B, Ye R, Phipps BM, Rambo RP, Hura GL, Pelikan M, So S, Abolfath RM, Chen DJ, Lees-Miller SP, Tainer JA (2010) Ku and DNA-dependent protein kinase dynamic conformations and assembly regulate DNA binding and the initial non-homologous end joining complex. J Biol Chem 285:1414-1423

32. Fang B (2014) Development of synthetic lethality anticancer therapeutics. J Med Chem 57 (19):7859-7873

33. Ma Y, Pannicke U, Schwarz K, Lieber MR (2002) Hairpin opening and overhang processing by an Artemis/DNA-dependent protein kinase complex in nonhomologous end joining and $\mathrm{V}$ (D)J recombination. Cell 108:781-794

34. Mahaney BL, Meek K, Lees-Miller SP (2009) Repair of ionizing radiation-induced DNA double-strand breaks by non-homologous end-joining. Biochem J 417:639-650

35. Pospiech H, Rytkinen AK, Syvaoja JE (2001) The role of DNA polymerase activity in human non-homologous end joining. Nucleic Acids Res 29:3277-3288

36. Dahm K (2008) Role and regulation of human XRCC4-like factor/Cernunnos. J Cell Biochem 104:1534-1540

37. Powis G, Bonjouklian R, Breggren MM, Gallegos A, Abraham R, Ashendel C, Zalkow L, Matter WF, Dodge J, Grindey G, Vlahos CJ (1994) Wortmannin, a potent and selective inhibitor of phosphatidylinositol-3-kinase. Cancer Res 54:2419-2423 
38. Wymann MP, Bulgarelli-Leva G, Zvelebil MJ, Pirola L, Vanhaesebroeck B, Waterfield MD, Panayotou G (1996) Wortmannin inactivates phosphoinositide 3-kinase by covalent modification of Lys-802, a residue involve in the phosphate transfer reaction. Mol Cell Biol 16:1722-1733

39. Walker EH, Pacold ME, Perisic O, Stephens L, Hawkins PT, Wymann MP, Williams RL (2000) Structural determinants of phosphoinositide 3-kinase inhibition by wortmannin, LY294002, quercetin, myricetin and staurosporine. Mol Cell 6:909-919

40. Izzard RA, Jackson SP, Smith GCM (1999) Competitive and noncompetitive inhibition of the DNA-dependent protein kinase. Cancer Res 59:2581-2586

41. Vlahos CJ, Matter WF, Hui KY, Brown RFA (1994) Specific inhibitor of phosphatidylinositol 3-kinase, 2-(4-morpholinyl)-8-phenyl-4H-1-benzopyran-4-one (LY294002). J Biol Chem 269:5241-5248

42. Griffin RJ, Fontana G, Golding BT, Guiard S, Hardcastle IR, Leahy JJJ, Martin N, Richardson C, Rigoreau L, Stockley M, Smith GCM (2005) Selective benzopyranone and pyrimido[2,1-a] isoquinolin-4-one inhibitors of DNA-dependent protein kinase: synthesis, structure-activity studies, and radiosensitization of a human tumor cell line in vitro. J Med Chem 48:569-585

43. Hardcastle IR, Cockcroft X, Curtin NJ, Desage-El Murr M, Leahy JJJ, Stockley M, Golding BT, Rigoreau L, Richardson C, Smith GCM, Griffin RJ (2005) Discovery of potent chromen4-one inhibitors of the DNA-dependent protein kinase (DNA-PK) using a small-molecule library approach. J Med Chem 48:7829-7846

44. Cano C, Barbeau RO, Bailey C, Cockcroft X, Curtin N, Duggan H, Frigerio M, Golding BT, Hardcastle IR, Hummersone MG, Knights C, Menear KA, Newell DR, Richardson C, Smith GCM, Spittle B, Griffin RJ (2010) DNA-dependent protein kinase (DNA-PK) inhibitors; synthesis and biological activity of quinolin-4-one and pyridopyrimidin-4-one surrogates for the chromen-4-one chemotype. J Med Chem 53:8498-8507

45. Veuger SJ, Curtin NJ, Richardson CJ, Smith GCM, Durkacz BW (2003) Radiosensitization and DNA repair inhibition by the combined use of novel inhibitors of DNA-dependent protein kinase and poly(ADP-ribose) polymerase-1. Cancer Res 63:6008-6015

46. Willmore E, de Caux S, Sunter NJ, Tilby MJ, Jackson GH, Austin CA, Durkacz BW (2004) A novel DNA-dependent protein kinase inhibitor, NU7026, potentiates the cytotoxicity of topoisomerase II poisons used in the treatment of leukemia. Blood 103:4659-4665

47. Hollick JJ, Rigoreau JM, Cano-Soumillac C, Cockcroft X, Curtin N, Frigerio M, Golding BT, Guiard S, Hardcastle IR, Hickson I, Hummersone MG, Menear KA, Martin N, Matthews I, Newell DR, Ord R, Richardson C, Smith GCM, Griffin RJ (2007) Pyranone, thiopyranone and pyridone inhibitors of phosphatidylinositol 3-kinase related kinases (PIKKs). Structureactivity relationships for DNA-dependent protein kinase (DNA-PK) inhibition, and identification of the first potent and selective inhibitor of the ataxia telangiectasia mutated (ATM) kinase. J Med Chem 50:1958-1972

48. Hollick JJ, Golding BT, Hardcastle IR, Martin N, Richardson C, Rigoreau L, Smith GCM, Griffin RJ (2003) 2,6-Disubstituted pyran-4-one and thiopyran-4-one inhibitors of DNA-dependent protein kinase (DNA-PK). Bioorg Med Chem Lett 13:3083-3086

49. Leahy JJJ, Golding BT, Griffin RJ, Hardcastle IR, Richardson C, Rigoreau L, Smith GCM (2004) Identification of a highly potent and selective DNA-dependent protein kinase (DNA-PK) inhibitor (NU7441) by screening of chromenone libraries. Bioorg Med Chem Lett 14:6083-6087

50. Zhao Y, Thomas HD, Batey M, Cowell I, Richardson C, Griffin R, Calvert AH, Newell DR, Smith GCM, Curtin N (2006) Preclinical evaluation of a potent novel DNA-dependent protein kinase inhibitor NU7441. Cancer Res 66:5354-5362

51. Tavecchio M, Munck JM, Cano C, Newell DR, Curtin NJ (2012) Further characterisation of the cellular activity of the DNA-PK inhibitor, NU7441, reveals potential cross-talk with homologous recombination. Cancer Chemother Pharmacol 69:155-164 
52. Cano C, Saravanan K, Bailey C, Bardos J, Curtin NJ, Frigerio M, Golding BT, Hardcastle IR, Hummersone MG, Menear KA, Newell DR, Richardson CJ, Shea K, Smith GCM, Thommes P, Ting A, Griffin RJ (2013) 1-Substituted (dibenzo[b,d]thiophen-4-yl)-2morpholino-4H-chromen-4-ones endowed with dual DNA-PK PI3-K inhibitory activity. J Med Chem 56:6386-6401

53. Munck JM, Batey MA, Zhao Y, Jenkins H, Richardson CJ, Cano C, Tavecchio M, Barbeau J, Bardos J, Griffin RJ, Menear K, Thommes P, Martin NMB, Newell DR, Smith GCM, Curtin NJ (2012) Chemosensitisation of cancer cells by KU-0060648; a dual inhibitor of DNA-PK and PI-3K. Mol Cancer Ther 11:1789-1798

54. Desage-El Murr M, Cano C, Golding BT, Hardcastle IR, Hummersone MG, Menear KA, Frigerio M, Curtin NJ, Richardson C, Smith GCM, Griffin RJ (2008) 8-Biarylchromen-4-one inhibitors of the DNA-dependent protein kinase (DNA-PK). Bioorg Med Chem Lett 18:4885-4890

55. Clapham K, Bardos J, Finlay R, Golding BT, Hardcastle IR, Menear KA, Newell DR, Turner P, Young G, Griffin RJ, Cano C (2011) DNA-dependent protein kinase (DNA-PK) inhibitors: structure-activity relationships for $O$-alkoxyphenylchromen-4-one probes of the ATP-binding domain. Bioorg Med Chem Lett 21:966-970

56. Cano C, Golding BT, Haggerty K, Hardcastle IR, Peacock M, Griffin RJ (2010) Atropisomeric 8-arylchromen-4-ones exhibit enantioselective inhibition of the DNA-dependent protein kinase (DNA-PK). Org Biomol Chem 8:1922-1928

57. Clapham KM, Rennison T, Jones G, Craven F, Bardos J, Golding BT, Griffin RJ, Haggerty K, Hardcastle IR, Thommes P, Cano C (2012) Potent enantioselective inhibition of DNA-dependent protein kinase (DNA-PK) by atropisomeric chromenone derivatives. Org Biomol Chem 10:6747-6757

58. Mould E, Berry P, Jamieson D, Hill C, Cano C, Tan N, Elliott S, Durkacz B, Newell D, Willmore E (2014) Identification of dual DNA-PK MDR1 inhibitors for the potentiation of cytotoxic drug activity. Biochem Pharmacol 88:58-65

59. Take Y, Kumano M, Hamano Y, Fukatsu H, Teraoka H, Nishimura S, Okuyama A (1995) OK-1035, a selective inhibitor of DNA-dependent protein kinase. Biochem Biophys Res Commun 215:41-47

60. Knight ZA, Chiang GG, Alaimo RJ, Kenski DM, Ho CB, Coan K, Abraham RT, Shokat KM (2004) Isoform-specific phosphoinositide-3-kinase inhibitors from an arylmorpholine scaffold. Bioorg Med Chem 12:4749-4759

61. Kashishian A, Douangpanya H, Clark D, Schlachter ST, Eary CT, Schiro JG, Huang H, Burgess LE, Kesicki EA, Halbrook J (2003) DNA-dependent protein kinase inhibitors as drug candidates for the treatment of cancer. Mol Cancer Ther 2:1257-1264

62. Shinohara ET, Geng L, Tan J, Chen H, Shir Y, Edwards E, Halbrook J, Kesicki EA, Kashishian A, Hallahan DE (2005) DNA-dependent protein kinase is a molecular target for the development of noncytotoxic rediation-sensitizing drugs. Cancer Res 65:4987-4992

63. Davidson D, Coulombe Y, Martinez-Marignac VL, Amrein L, Grenier J, Hodkinson K, Masson J, Aloyz R, Panasci L (2012) Irinotecan and DNA-PKcs inhibitors synergize in killing of colon cancer cells. Invest New Drugs 30:1248-1256

64. Davidson D, Grenier J, Martinez-Marignac VL, Amrein L, Shawi M, Tokars M, Aloyz R, Panasci L (2012) Effects of the novel DNA dependent protein kinase inhibitor, IC486241, on the DNA damage response to doxorubicin and cisplatin in breast cancer cells. Invest New Drugs 30:1736-1742

65. Hassan I, Martensson S, Moshinsky D, Rice A, Tang C, Howlett A, McMahon G, Hammarsten O (2004) SU11752 inhibits the DNA-dependent protein kinase and DNA double-strand break repair resulting in ionizing radiation sensitization. Oncogene 23:873-882

66. Maxwell JP, Charifson PS, Tang Q, Ronkin SM, Jackson KL, Pierce AC, Lauffer DJ, Li P, Giroux S (2014) DNA-PK inhibitors. US Patent 2014/0275059 A1, 18 Sept 2014 
67. Boucher D, Hoover R, Wang Y, Gu Y, Newsome D, Ford P, Moody C, Damagnez V, Arimoto R, Hillier S, Wood M, Markland W, Eustace B, Cottrell K, Penney M, Furey B, Tanner K, Maxwell J, Charifson P (2016) Potent radiation enhancement with VX-984, a selective DNA-PKcs inhibitor for the treatment of NSCLC. Proc Amer Assoc Cancer Res, Abstract 3716

68. Lempiäinen H, Halazonetis TD (2009) Emerging common themes in regulation of PIKKs and PI3Ks. EMBO J 28:3067-3073

69. Lavin MF, Khanna KK (1999) ATM: the protein encoded by the gene mutated in the radiosensitive syndrome ataxia-telangiectasia. Int J Radiat Biol 75:1201-1214

70. Dumaz N, Meek DW (1999) Serine 15 phosphorylation stimulates p53 transactivation but does not directly influence interaction with HDM2. EMBO J 18:7002-7010

71. Harper JW, Adami GR, Wei N, Keyomarsi K, Elledge SJ (1993) The p21 Cdk-interacting protein Cip1 is a potent inhibitor of $\mathrm{G}_{1}$ cyclin-dependent kinases. Cell 75:805-816

72. Unger T, Juven-Gershon T, Moallem E, Berger M, Sionov RV, Lozano G, Oren M, Haupt Y (1999) Critical role for Ser20 of human p53 in the negative regulation of p53 by MDM2. EMBO J 18:1805-1814

73. Shiloh Y (2001) ATM and ATR: networking cellular responses to DNA damage. Curr Opin Genet Dev 11:71-77

74. Suzuki K, Kodama S, Watanabe M (1999) Recruitment of ATM protein to double strand DNA irradiated with ionizing radiation. J Biol Chem 274:25571-25575

75. Ding J, Miao Z-H, Meng L-H, Geng M-Y (2006) Emerging cancer therapeutic opportunities target DNA-repair systems. Trends Pharmacol Sci 27:338-344

76. Hickson I, Zhao Y, Richardson CJ, Green SJ, Martin NMB, Orr AI, Reaper PM, Jackson SP, Curtin NJ, Smith GC (2004) Identification and characterization of a novel and specific inhibitor of the ataxia-telangiectasia mutated kinase ATM. Cancer Res 64:9152-9159

77. Andrs M, Korabecny J, Jun D, Hodny Z, Bartek J, Kuca K (2014) Phosphatidylinositol 3-kinase (PI3K) and phosphatidylinositol 3-kinase-related kinase (PIKK) inhibitors: importance of the morpholine ring. J Med Chem 58:41-71

78. Golding SE, Rosenburg E, Valerie N, Hussaini I, Frigerio M, Cockroft XF, Chong WY, Hummersone M, Rigoreau L, Menear KA, O’Connor MJ, Povirk LF, van Meter T, Valerie K (2009) Improved ATM kinase inhibitor KU-60019 radiosensitizes glioma cells, compromises insulin, AKT and ERK prosurvival signaling, and inhibits migration and invasion. Mol Cancer Ther 8:2894-2902

79. Batey MA, Zhao Y, Kyle S, Richardson C, Slade A, Martin NM, Lau A, Newell DR, Curtin NJ (2013) Preclinical evaluation of a novel ATM inhibitor, KU59403, in vitro and in vivo in p53 functional and dysfunctional models of human cancer. Mol Cancer Ther 12:959-967

80. Degorce SL, Barlaam B, Cadogan E, Dishington A, Ducray R, Glossop SC, Hassall LA, Lach F, Lau A, McGuire TM, Nowak T, Ouvry G, Pike KG, Thomason AG (2016) Discovery of novel 3-quinoline carboxamides as potent, selective, and orally bioavailable inhibitors of ataxia telangiectasia mutated (ATM) kinase. J Med Chem 59:6281-6292

81. Chen X, Zhao R, Glick GG, Cortez D (2007) Function of the ATR N-terminal domain revealed by an ATM/ATR chimera. Exp Cell Res 313:1667-1674

82. Cimprich K, Cortez D (2008) ATR: an essential regulator of genome integrity. Nat Rev Mol Cell Biol 9:616-627

83. Lakin ND, Hann BC, Jackson SP (1999) The ataxia-telangiectasia related protein ATR mediates DNA-dependent phosphorylation of p53. Oncogene 18:3989-3995

84. Tibbetts RS, Brumbaugh KM, Williams JM, Sarkaria JN, Cliby WA, Shieh SY, Taya Y, Prives C, Abraham RT (1999) A role for ATR in the DNA damage-induced phosphorylation of p53. Genes Dev 13:152-157

85. Liu Q, Guntuku S, Cui X-S, Matsuoka S, Cortez D, Tami K, Luo G, Carattini-Rivera S, DeMayo F, Bradley A, Donehower LA, Elledge SJ (2000) Chk1 is an essential kinase that is regulated by ATR and required for the $\mathrm{G}_{2} / \mathrm{M}$ DNA damage checkpoint. Genes Dev $14: 1448-1459$ 
86. Nishida H, Tatewaki N, Nakajima Y, Magara T, Ko KM, Hamamori Y, Konishi T (2009) Inhibition of ATR protein kinase activity by schisandrin B in DNA damage response. Nucleic Acids Res 37:5678-5689

87. Knight ZA, Gonzalez B, Feldman ME, Zunder ER, Goldenberg DD, Williams O, Loewith R, Stokoe D, Balla A, Toth B, Balla T, Weiss WA, Williams RL, Shokat KM (2006) A pharmacological map of the PI3-K family defines a role for p110alpha in insulin signalling. Cell 125:733-747

88. Rosenzweig KE, Youmell MB, Palayoor ST, Price BD (1997) Radiosensitization of human tumor cells by the phosphatidylinositol-3-kinase inhibitors wortmannin and LY294002 correlates with inhibition of DNA-dependent protein kinase and prolonged G2-M delay. Clin Cancer Res 3:1149-1156

89. Lee CM, Fuhrman CB, Planelles V, Peltier MR, Gaffney DK, Soisson AP, Dodson MK, Tolley HD, Green CL, Zempolich KA (2006) Phosphatidylinositol 3-kinase inhibition by LY294002 radiosensitizes human cervical cancer cell lines. Clin Cancer Res 12:250-256

90. Sarkaria JN, Tibbetts RS, Busby EC, Kennedy AP, Hill DE, Abraham RT (1998) Inhibition of phosphoinositide 3-kinase related kinases by the radiosensitizing agent wortmannin. Cancer Res 58:4375-4382

91. Sarkaria JN, Busby EC, Tibbetts RS, Roos P, Taya Y, Karnitz LM, Abraham RT (1999) Inhibition of ATM and ATR kinase activities by the radiosensitizing agent, caffeine. Cancer Res 59:4375-4382

92. Nishida H, Hamamori Y, Konishi T (2007) ATR Inhibitor. Patent WO2007046426A1, Niigata Tlo Corp., Japan

93. Liu Q, Xu C, Kirubakaran S, Zhang X, Hur W, Liu Y, Kwiatkowski NP, Wang J, Westover KD, Gao P, Ercan D, Niepel M, Thoreen CC, Kang SA, Patricelli MP, Wang Y, Tupper T, Altabef A, Kawamura H, Held KD, Chou DM, Elledge SJ, Janne PA, Wong K-K, Sabatini DM, Gray NS (2013) Characterization of Torin2, an ATP-competitive inhibitor of mTOR, ATM, and ATR. Cancer Res 73:2574-2586

94. Toledo LI, Murga M, Zur R, Soria R, Rodriguez A, Martinez S, Oyarzabal J, Pastor J, Bischoff JR, Fernandez-Capetillo O (2011) A cell-based screen identifies ATR inhibitors with synthetic lethal properties for cancer-associated mutations. Nat Struct Mol Biol 18:721-727

95. Liu Q, Wang J, Kang SA, Thoreen CC, Ahmed T, Sabatini DM, Gray NS (2011) Discovery of 9-(6-aminopyridin-3-yl)-1-(3-(trifluoromethyl)phenyl)benzo[ $h][1,6]$ naphthyridin-2(1H)-one (Torin2) as a potent, selective, and orally available mammalian target of rapamycin (mTOR) inhibitor for treatment of cancer. J Med Chem 54:1473-1480

96. Toledo LI, Murga M, Gutierrez-Martinez P, Soria R, Fernandez-Capetillo O (2008) ATR signaling can drive cells into senescence in the absence of DNA breaks. Genes Dev 22:297-302

97. Peasland A, Wang L-Z, Rowling E, Kyle S, Chen T, Hopkins A, Cliby WA, Sarkaria J, Beale G, Edmondson RJ, Curtin NJ (2011) Identification and evaluation of a potent novel ATR inhibitor, NU6027, in breast and ovarian cancer cell lines. Br J Cancer 105:372-381

98. Maira S-M, Stauffer F, Brueggen J, Furet P, Schnell C, Fritsch C, Brachmann S, Chène P, De Pover A, Schoemaker K, Fabbro D, Gabriel D, Simonen M, Murphy L, Finan P, Sellers W, García-Echeverría C (2008) Identification and characterization of NVP-BEZ235, a new orally available dual phosphatidylinositol 3-kinase/mammalian target of rapamycin inhibitor with potent in vivo antitumor activity. Mol Cancer Ther 7:1851-1863

99. Wang H-C, Lee AY, Chou WC, Wu CC, Tseng CN, Liu KY, Lin WL, Chang FR, Chuang DW, Hunyadi A, Wu YC (2012) Inhibition of ATR-dependent signaling by protoapigenone and its derivative sensitizes cancer cells to interstrand cross-link-generating agents in vitro and in vivo. Mol Cancer Ther 11:1443-1453

100. Wang H-C, Lee AY-L, Wu C-C, Wu Y-C (2014) Discovery of ATR kinase inhibitors from natural products. Proceedings of the $105^{\text {th }}$ Annual Meeting of the AACR; 2014 Apr 5-9 San Diego, CA. Cancer Res 74(19 Suppl):Abstract nr 1637 
101. Jacq X, Smith L, Brown E, Hughes A, Odedra R, Heathcote D, Barnes J, Powell S, Maguire S, Pearson V, Boros J, Caie P, Thommes PA, Nissink W, Foote K, Jewsbury PJ, Guichard S (2012) AZ20, a novel potent and selective inhibitor of ATR kinase with in vivo antitumour activity. Proceedings of the $103^{\text {rd }}$ Annual Meeting of the AACR; 2012 Mar 31-Apr 4 Chicago. Cancer Res 72(8 Suppl):Abstract nr 1823

102. Foote KM, Blades K, Cronin A, Fillery S, Guichard SS, Hassall L, Hickson I, Jacq X, Jewsbury PJ, McGuire TM, Nissink JW, Odedra R, Page K, Perkins P, Suleman A, Tam K, Thommes P, Broadhurst R, Wood C (2013) Discovery of 4-\{4-[(3R)-3-methylmorpholin-4yl]-6-[1-(methylsulfonyl)cyclopropyl]pyrimidin-2-yl $\}-1 H$-indole (AZ20): a potent and selective inhibitor of ATR protein kinase with monotherapy in vivo antitumor activity. J Med Chem 56:2125-2138

103. Jones CD, Blades K, Foote KM, Guichard SM, Jewsbury PJ, McGuire T, Nissink JW, Odedra R, Tam K, Thommes P, Turner P, Wilkinson G, Wood C, Yates JW (2013) Discovery of AZD6738, a potent and selective inhibitor with the potential to test the clinical efficacy of ATR kinase inhibition in cancer patients. Proceedings of the $104^{\text {th }}$ Annual Meeting of the AACR; 2013 Apr 6-Apr 10 Washington DC. Cancer Res 73(8 Suppl):Abstract nr 2348

104. Guichard SM, Brown E, Odedra R, Hughes A, Heathcote D, Barnes J, Lau A, Powell S, Jones CD, Nissink W, Foote KM, Jewsbury PJ, Pass M (2013) The pre-clinical in vitro and in vivo activity of AZD6738: a potent and selective inhibitor of ATR kinase. Proceedings of the $104^{\text {th }}$ Annual Meeting of the AACR; 2013 Apr 6-Apr 10 Washington DC. Cancer Res 73(8 Suppl): Abstract nr 3343

105. Charrier J-D, Durrant SJ, Knegtel RMA, Virani AN, Reaper PM (2011) Compounds useful as inhibitors of ATR kinase. Patent WO2011143425A2, Vertex Pharmaceuticals Inc., USA

106. Reaper PM, Griffiths MR, Long JM, Charrier J-D, MacCormick S, Charlton PA, Golec JMC, Pollard JR (2011) Selective killing of ATM- or p53-deficient cancer cells through inhibition of ATR. Nat Chem Biol 7:428-430

107. Charrier J-D, Durrant SJ, Golec JMC, Kay DP, Knegtel RMA, MacCormick S, Mortimore M, O'Donnell ME, Pinder JL, Reaper PM, Rutherford AP, Wang PSH, Young SC, Pollard JR (2011) Discovery of potent and selective inhibitors of ataxia telangiectasia mutated and $\operatorname{Rad} 3$ related (ATR) protein kinase as potential anticancer agents. J Med Chem 54:2320-2330

108. Fokas E, Prevo R, Pollard JR, Reaper PM, Charlton PA, Cornelissen B, Vallis KA, Hammond EM, Olcina MM, Gillies McKenna W, Muschel RJ, Brunner TB (2012) Targeting ATR in vivo using the novel inhibitor VE-822 results in selective sensitization of pancreatic tumors to radiation. Cell Death Dis 3:e441

109. Hall AB, Newsome D, Wang Y, Boucher DM, Eustace B, Gu Y, Hare B, Johnson MA, Milton S, Murphy CE, Takemoto D, Tolman C, Wood M, Charlton P, Charrier JD, Furey B, Golec J, Reaper PM, Pollard JR (2014) Potentiation of tumor responses to DNA damaging therapy by the selective ATR inhibitor VX-970. Oncotarget 5:5674-5685 